\title{
GOLUM-CNP v1.0: a data-driven modeling of carbon, nitrogen and phosphorus cycles in major terrestrial biomes
}

\author{
Yilong Wang ${ }^{1}$, Philippe Ciais ${ }^{1}$, Daniel Goll ${ }^{1}$, Yuanyuan Huang ${ }^{1}$, Yiqi Luo ${ }^{2,3,4}$, Ying-Ping Wang ${ }^{5}$, A. Anthony Bloom ${ }^{6}$, \\ Grégoire Broquet $^{1}$, Jens Hartmann ${ }^{7}$, Shushi Peng ${ }^{8}$, Josep Penuelas ${ }^{9,10}$, Shilong Piao ${ }^{8,11}$, Jordi Sardans ${ }^{9,10}$, \\ Benjamin D. Stocker ${ }^{10}$, Rong Wang ${ }^{12}$, Sönke Zaehle ${ }^{13}$, and Sophie Zechmeister-Boltenstern ${ }^{14}$ \\ ${ }^{1}$ Laboratoire des Sciences du Climat et de l'Environnement, CEA-CNRS-UVSQ- Université Paris Saclay, \\ Gif-sur-Yvette, France \\ ${ }^{2}$ Center for Ecosystem Science and Society, Northern Arizona University, Flagstaff, AZ, USA \\ ${ }^{3}$ Department of Earth System Science, Tsinghua University, Beijing, China \\ ${ }^{4}$ Department of Microbiology and Plant Biology, University of Oklahoma, Norman, OK, USA \\ ${ }^{5}$ CSIRO Oceans and Atmosphere, PMB 1, Aspendale, Victoria, Australia \\ ${ }^{6}$ Jet Propulsion Laboratory, California Institute of Technology, Pasadena, CA, USA \\ ${ }^{7}$ Institute for Geology, KlimaCampus, Universität Hamburg, Bundesstrasse 55, 20146 Hamburg, Germany \\ ${ }^{8}$ Sino-French Institute for Earth System Science, College of Urban and Environmental Sciences, \\ Peking University, Beijing, China \\ ${ }^{9}$ CSIC, Global Ecology Unit CREAF-CSIC-UAB, Bellaterra, Catalonia, Spain \\ ${ }^{10}$ CREAF, Cerdanyola del Vallès, Catalonia, Spain \\ ${ }^{11}$ Institute of Tibetan Plateau Research, Chinese Academy of Sciences, Beijing, China \\ ${ }^{12}$ Department of Global Ecology, Carnegie Institution for Science, Stanford, CA, USA \\ ${ }^{13}$ Max Planck Institute for Biogeochemistry, Jena, Germany \\ ${ }^{14}$ University of Natural Resources and Life Sciences Vienna, Institute of Soil Research, \\ Department of Forest and Soil Sciences, Vienna, Austria
}

Correspondence: Yilong Wang (yilong.wang@1sce.ipsl.fr)

Received: 30 January 2018 - Discussion started: 22 March 2018

Revised: 26 August 2018 - Accepted: 3 September 2018 - Published: 27 September 2018

\begin{abstract}
Global terrestrial nitrogen (N) and phosphorus (P) cycles are coupled to the global carbon (C) cycle for net primary production (NPP), plant $\mathrm{C}$ allocation, and decomposition of soil organic matter, but $\mathrm{N}$ and $\mathrm{P}$ have distinct pathways of inputs and losses. Current $\mathrm{C}$-nutrient models exhibit large uncertainties in their estimates of pool sizes, fluxes, and turnover rates of nutrients, due to a lack of consistent global data for evaluating the models. In this study, we present a new model-data fusion framework called the Global Observation-based Land-ecosystems Utilization Model of Carbon, Nitrogen and Phosphorus (GOLUM-CNP) that combines the CARbon DAta MOdel fraMework (CARDAMOM) data-constrained C-cycle analysis with spatially explicit data-driven estimates of $\mathrm{N}$ and $\mathrm{P}$ inputs and losses and with observed stoichiometric ratios. We calculated the
\end{abstract}

steady-state $\mathrm{N}$ - and P-pool sizes and fluxes globally for large biomes. Our study showed that new $\mathrm{N}$ inputs from biological fixation and deposition supplied $>20 \%$ of total plant uptake in most forest ecosystems but accounted for smaller fractions in boreal forests and grasslands. New P inputs from atmospheric deposition and rock weathering supplied a much smaller fraction of total plant uptake than new $\mathrm{N}$ inputs, indicating the importance of internal $P$ recycling within ecosystems to support plant growth. Nutrient-use efficiency, defined as the ratio of gross primary production (GPP) to plant nutrient uptake, were diagnosed from our model results and compared between biomes. Tropical forests had the lowest $\mathrm{N}$-use efficiency and the highest P-use efficiency of the forest biomes. An analysis of sensitivity and uncertainty indicated that the NPP-allocation fractions to leaves, roots, and 
wood contributed the most to the uncertainties in the estimates of nutrient-use efficiencies. Correcting for biases in NPP-allocation fractions produced more plausible gradients of $\mathrm{N}$ - and P-use efficiencies from tropical to boreal ecosystems and highlighted the critical role of accurate measurements of $\mathrm{C}$ allocation for understanding the $\mathrm{N}$ and $\mathrm{P}$ cycles.

\section{Introduction}

Nitrogen $(\mathrm{N})$ and phosphorus $(\mathrm{P})$ cycling are tightly coupled with the global carbon (C) cycle (Cleveland et al., 2013; Elser et al., 2007; Gruber and Galloway, 2008; Ver et al., 1999; Turner et al., 2018) in terrestrial ecosystems. $\mathrm{N}$ and $\mathrm{P}$ availability affects vegetation productivity, growth, and other processes (Norby et al., 2010; Sutton et al., 2008; Vitousek and Howarth, 1991). N and $\mathrm{P}$ also affect soil $\mathrm{C}$ by nutrient controls on the mineralization of litter and soil organic matter (SOM; Gärdenäs et al., 2011; Melillo et al., 2011). Global vegetation models suggest that the coupling between the $C$, $\mathrm{N}$, and $\mathrm{P}$ cycles is among the major factors determining projected changes in the terrestrial $\mathrm{C}$ balance under scenarios of climate change and rising atmospheric $\mathrm{CO}_{2}$, because additional productivity will only be realized if plants can increase their uptake or recycling of nutrients (Hungate et al., 2003; Sun et al., 2017; Wang and Houlton, 2009; Zaehle et al., 2015). Estimates of the magnitudes of these responses of ecosystems in the future, however, are highly uncertain (Peñuelas et al., 2013; Wieder et al., 2015).

Nutrients are important for understanding the current perturbation and future projections of the global $\mathrm{C}$ cycle, so several dynamic global vegetation models (DGVMs) have incorporated terrestrial N cycling (Goll et al., 2012; Medvigy et al., 2009; Parton et al., 2010; Thornton et al., 2007; Wang et al., 2001, 2010; Weng and Luo, 2008; Xu-Ri and Prentice, 2008; Yang et al., 2009; Zaehle et al., 2014; Zaehle and Friend, 2010). Fewer models have incorporated the cycling of $\mathrm{P}$ and its interactions with $\mathrm{C}$ dynamics (Goll et al., 2012, 2017a; Wang et al., 2010). Many of the underlying processes are not fully understood, and comprehensive data for evaluation are lacking to constrain the representation of some key processes (Zaehle et al., 2014), so model structure, the processes included, and the prescribed parameters differ widely among DGVMs (Zaehle and Dalmonech, 2011). For example, some models assume constant stoichiometry $(\mathrm{N}: \mathrm{C}$ and $\mathrm{P}: \mathrm{C}$ ratios) in plant tissues (Thornton et al., 2007; Weng and Luo, 2008), while others have a flexible stoichiometry (Wang et al., 2010; Xu-Ri and Prentice, 2008; Yang et al., 2009; Zaehle and Friend, 2010). For the N cycle, for instance, some models do not include losses of gaseous $\mathrm{N}$ from denitrification (Medvigy et al., 2009), some use the "hole-in-thepipe" approach to simulate the denitrification flux (Thornton et al., 2007; Wang et al., 2010), assuming it is proportional to net $\mathrm{N}$ mineralization, while others calculate this flux as a function of soil N-pool size and soil conditions (temperature, moisture, pH, etc.) (Parton et al., 2010; Xu-Ri and Prentice, 2008; Zaehle and Friend, 2010). For the P cycle, for instance, Jahnke (2000) estimated that the global total amount of soil P was $200 \mathrm{Pg}$ and that the $\mathrm{P}$ contained in plants was $3 \mathrm{Pg}$, based on empirical $\mathrm{P}$ content of soils $(0.1 \%)$ and soil thickness $(60 \mathrm{~cm})$. These estimates were questioned by recent studies from Wang et al. (2010) and Goll et al. (2012), who estimated that $\mathrm{P}$ in plants ranged between 0.23 and $0.39 \mathrm{Pg}$ and that $\mathrm{P}$ in soil was only $26.5 \mathrm{Pg}$ based on $\mathrm{P}: \mathrm{C}$ ratios derived from more comprehensive stoichiometric data sets. Furthermore, terrestrial ecosystem models are usually only evaluated for specific ecosystems or at a limited number of sites (Goll et al., 2017a; Yang et al., 2014a). The application of these models for simulations with global coverage is thus highly uncertain (Goll et al., 2012; Wang et al., 2010; Zhang et al., 2011).

A growing number of data sets in recent decades have addressed many aspects of the nutrient cycles and their interactions with $\mathrm{C}$ dynamics. For example, ZechmeisterBoltenstern et al. (2015) synthesized the stoichiometry in different ecosystem compartments and highlighted the latitudinal gradients of plant, litter, and soil stoichiometry. Liu et al. (2017) evaluated soil net $\mathrm{N}$ mineralization among different ecosystems at the global scale and found that net $\mathrm{N}$ mineralization decreased with increasing latitude. They also found that the $\mathrm{N}$ mineralization at higher latitudes is more sensitive to temperature changes than at lower latitudes, indicating potential alleviation of $\mathrm{N}$ limitation for plants' productivity at boreal regions under global warming. Yang et al. (2013) provided spatially explicit estimates of different forms of soil $\mathrm{P}$ globally and thus made it possible to assess the $\mathrm{P}$ content that is available for plant uptake. These data help to improve the understanding of the global terrestrial biogeochemical cycles across large climatic and ecological gradients and can in principle be combined to provide an integrated analysis of terrestrial C, N, and P cycles. Estimates of $\mathrm{C}, \mathrm{N}$, and $\mathrm{P}$ cycles consistent with all these data sets, however, have not yet been successfully provided due to the difficulties in combining these data sets with different uncertainties and inconsistent spatiotemporal representations.

We present a new global data-driven diagnostic of $\mathrm{C}$, $\mathrm{N}$, and P pools and fluxes, called GOLUM-CNP (Global Observation-based Land-ecosystems Utilization Model of Carbon, Nitrogen and Phosphorus) which is based on the assumption that these cycles are equilibrated with present day conditions (see below for limitations of this approach). The goals of this study are to (1) establish a global datadriven diagnostics of $\mathrm{C}, \mathrm{N}$, and $\mathrm{P}$ fluxes and pools in order to compare nutrient-use efficiencies, nutrient turnover rates, and other relevant indicators across biomes; and (2) provide a new data set that can be used to evaluate the results of global terrestrial biosphere models with consistent state of $\mathrm{C}, \mathrm{N}$, and $\mathrm{P}$ cycles. In GOLUM-CNP, the $\mathrm{C}, \mathrm{N}$, and $\mathrm{P}$ cycles were estimated for different biomes assuming a steady state with present-day input of carbon (NPP), nitrogen (N 
deposition and $\mathrm{N}$ fixation) and phosphorus (P deposition and release from rock weathering) (see Sect. 3.2). The reason for this steady-state computation lies in the fact that only few global long-term observations associated with $\mathrm{N}$ and $\mathrm{P}$ cycles are available and are insufficient to constrain a transient simulation under the model framework. For example, fieldscale manipulation experiments have shown that warming, elevated atmospheric $\mathrm{CO}_{2}$, and $\mathrm{N}$ and $\mathrm{P}$ fertilization can drive changes in stoichiometry and nutrient resorptions (Sistla and Schimel, 2012; Sardans et al., 2012; Sardans and Peñuelas, 2012; Mayor et al., 2014; Yang et al., 2014b; Yuan and Chen, 2015; Sardans et al., 2016, 2017) in terrestrial ecosystems, but these data are insufficient to infer these changes in terrestrial ecosystems during the past decades. As more data become available, the model framework can be adjusted to simulate a transient present-day state. Although, the steady-state assumption hampers the comparison of stocks with presentday observations, a direct comparison with simulated steady states of DGVM is possible as these models can simulate the steady state for present-day conditions.

Starting from a CARbon DAta MOdel fraMework (CARDAMOM) data-constrained analysis of the terrestrial C cycle (Bloom et al., 2016), which is based on the Data Assimilation Linked Ecosystem Carbon Model version two (DALEC2; Bloom and Williams, 2015; Williams et al., 2005) and on observations of biomass, soil C, leaf area index (LAI), and fire emissions, we incorporated observed stoichiometric ratios $(\mathrm{C}: \mathrm{N}: \mathrm{P})$ in each pool, $\mathrm{N}$ and $\mathrm{P}$ external input fluxes, transformations and losses in ecosystems, and the fraction of gaseous losses of $\mathrm{N}$ to total (gaseous and leaching) losses of $\mathrm{N}$ from a global data set of ${ }^{15} \mathrm{~N}$ measurements in soils. Although the diagnostics is presented for the steady state, the methods used to compute fluxes and pools are generic and could be extended to the non-steady state (see Sect. 2 and equations in Appendices A-C) when more data will become available in the future (see Sect. 5.3).

We first present the model structure (Sect. 2) and the data sets used to derive its outputs consisting of pools, fluxes, and turnovers of $\mathrm{C}, \mathrm{N}$, and $\mathrm{P}$ (Sect. 3). The model results and their sensitivities to the input observation-based data sets are then further analyzed in Sect. 4. In Sect. 5, we show examples of the application of this sensitivity analysis to identify the major differences in the results from our model framework and a synthesis of in situ measurements, and a qualitative example of how to compare the model and the independent data. These differences identify critical observations to reduce uncertainty in global $\mathrm{C}$ and nutrient cycling and highlight the future demand for model development, calibration, and evaluation.

\section{Model structure}

GOLUM-CNP describes the $\mathrm{C}, \mathrm{N}$, and $\mathrm{P}$ cycles in natural (i.e., non-agricultural) terrestrial ecosystems (Fig. 1). We

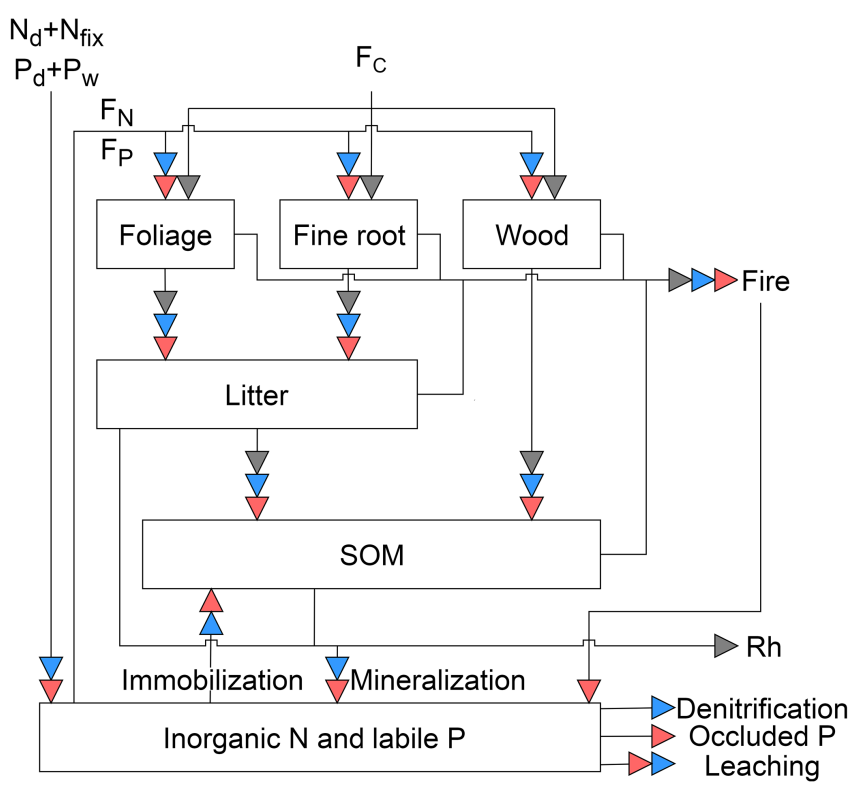

Figure 1. Schematic representation of the pools and fluxes in the $\mathrm{C}, \mathrm{N}$, and $\mathrm{P}$ cycles within GOLUM-CNP. The gray, blue, and red arrows represent $\mathrm{C}, \mathrm{N}$, and $\mathrm{P}$ fluxes, respectively. Plants are divided into foliar, fine root, and wood pools, where the wood pool includes woody stems and coarse roots. Litter and soil are two separate pools. The inorganic pool represents the nutrient sources in the soil that are available for plant uptake. Arrows between the pools represent the directions of $\mathrm{C}, \mathrm{N}$, and $\mathrm{P}$ flow between pools. External inputs of $\mathrm{N}$ are atmospheric deposition $\left(N_{\mathrm{d}}\right)$ and biological $\mathrm{N}$ fixation $\left(N_{\mathrm{fix}}\right)$. External inputs of $\mathrm{P}$ are atmospheric deposition $\left(P_{\mathrm{d}}\right)$ and $\mathrm{P}$ released by rock weathering $\left(P_{\mathrm{W}}\right) . F_{\mathrm{C}}$ is net primary production $(\mathrm{NPP}) . F_{\mathrm{N}}$ and $F_{\mathrm{P}}$ are plant uptake of $\mathrm{N}$ and $\mathrm{P}$ from the inorganic $\mathrm{N}$ and labile $\mathrm{P}$ pools, respectively. $R_{\mathrm{h}}$ is release of $\mathrm{C}$ due to heterotrophic respiration. Mineralization of $\mathrm{N}$ and $\mathrm{P}$ is modeled along with litter and SOM decomposition, and $\mathrm{N}$ and $\mathrm{P}$ immobilization is modeled by a flux from the inorganic pool to SOM. External losses of N occur by fire, leaching, and denitrification. External losses of $\mathrm{P}$ occur by fire, leaching, and transfer to occluded $\mathrm{P}$ in the soil.

used the same $\mathrm{C}$ pools and fluxes as in the CARDAMOM diagnostic (see Sect. 2.1 for details) to describe the $\mathrm{C}$ cycle and we computed associated $\mathrm{N}$ and $\mathrm{P}$ pools and fluxes. Biomass is divided into three pools: foliage, fine roots, and wood. The wood pool includes woody stems, branches, and coarse roots. The litter pool in Fig. 1 corresponds to fine litter from leaves and fine roots. SOM receives $\mathrm{C}$ from fine litter and woody biomass. Two additional pools not present in CARDAMOM are added, representing soil inorganic $\mathrm{N}$ and labile soil $\mathrm{P}$. These inorganic $\mathrm{N}$ and labile soil $\mathrm{P}$ pools are assumed to represent nutrients accessible by plants (see Sect. 2.1 and 2.2). Of note is that these inorganic $\mathrm{N}$ and labile soil $\mathrm{P}$ pools represent an integration of various forms of $\mathrm{N}$ and $\mathrm{P}$. For example, $\mathrm{P}$ has various forms in the soil and can be transformed between those forms (Wang et al., 2007; Yang and Post, 2011). Some forms of organic P (e.g., bicarbonate Po in the Hedley method, Yang and Post, 2011) can easily be mineralized and 
thus were implicitly included in our labile soil $\mathrm{P}$ pool. Other forms of $\mathrm{P}$ that are not easily accessible to plants are referred to as "occluded P" and labile soil P can become occluded P (Wang et al., 2010; Goll et al., 2017a). Fluxes connecting the pools are described by the differential equations given in Appendices A-C. An overview of the $\mathrm{C}, \mathrm{N}$, and $\mathrm{P}$ cycles and their interactions are presented in the following sections. A full list of the symbols and their definitions is given in Table 1 .

\subsection{C cycle}

The $\mathrm{C}$ cycle in the GOLUM-CNP model is based on the DALEC2 model (Bloom et al., 2016; Bloom and Williams, 2015). We used a similar structure to define the $C$ pools of GOLUM-CNP but grouped the DALEC2 foliar and labile vegetation $\mathrm{C}$ pools into a single foliar pool (Fig. 1). Net primary production (NPP) is allocated to the three biomass pools. The outgoing fluxes from biomass pools include losses from fire, the transfer of foliage, and root detritus to litter and the transfer of wood debris directly to the SOM pool. The outgoing fluxes from litter include losses from fire and decomposition. A fraction of decomposed litter is respired and returned to the atmosphere as $\mathrm{CO}_{2}$, the remaining fraction being converted to SOM. The SOM pool loses $\mathrm{C}$ by fire and decomposition. Differential equations governing the dynamics of $\mathrm{C}$ pools are given in Appendix A.

\subsection{N cycle}

The N cycle in GOLUM-CNP is coupled to the $\mathrm{C}$ cycle: the pool sizes of $\mathrm{N}$ are determined by the $\mathrm{C}$-pool sizes and their respective $\mathrm{N}$ : $\mathrm{C}$ ratios; the $\mathrm{N}$ fluxes from different pools are determined by the $\mathrm{N}$-pool sizes and corresponding turnover rates. The $\mathrm{N}$ cycle includes a specific soil inorganic-N pool in addition to the five pools of the $\mathrm{C}$ cycle. The inputs of $\mathrm{N}$ to ecosystems include atmospheric $\mathrm{N}$ deposition and $\mathrm{N}$ fixation $\left(N_{\mathrm{d}}+N_{\text {fix }}\right.$; please check in Fig. 1), both of which are assumed to enter the inorganic- $\mathrm{N}$ pool. The total $\mathrm{N}$-fixation flux in this study includes both symbiotic and asymbiotic fixation (see Sect. 3.1), separately estimated from a previous study (see Sect. 3.1). We do not separate the two fixation processes and assume that they together contribute to the inorganic- $\mathrm{N}$ pool, although these two pathways of $\mathrm{N}$ fixation are differed in terms of the relationships between $\mathrm{N}_{2}$-fixing microorganisms and plants. We did not consider the flux of $\mathrm{N}$ mobilized from near-surface rocks, although a recent paper by Houlton et al. (2018) pointed out this flux may be an important $\mathrm{N}$ source in montane and high-latitude ecosystems. $\mathrm{N}$ uptake $\left(F_{\mathrm{N}}\right)$ by plants is assumed to be solely from the inorganic- $\mathrm{N}$ pool. Organic $\mathrm{N}$ is an important $\mathrm{N}$ supply for plants (Näsholm et al., 2009) in boreal-forest and tundra ecosystems (Schimel and Bennett, 2004; Schimel and Chapin, 1996; Zhu and Zhuang, 2013), but the quantitative importance of this process is still unknown for other ecosys- tems globally. We thus ignored the uptake of organic soil N. $\mathrm{N}$ uptake by plants from the inorganic- $\mathrm{N}$ pool is modeled from the N : C ratio of NPP allocated to biomass pools minus the resorbed $\mathrm{N}$. In the real world, $\mathrm{N}$ is only resorbed at the end of the growing season or leaf lifespan and then stored in plant organs and remobilized during the next growing season. Here, because our model does not have a sub-annual time step, rates of resorption described by a resorption coefficient (Appendix B) are assumed to be constant over time. We also assumed that $\mathrm{N}$ is not resorbed from fine roots or wood, because evidence for this process is inconclusive (Gordon and Jackson, 2000; Zechmeister-Boltenstern et al., 2015). N mineralization is modeled along with litter and SOM decomposition. $\mathrm{N}$ immobilization due to the uptake of inorganic soil $\mathrm{N}$ by soil organisms is modeled to match the higher $\mathrm{N}: \mathrm{C}$ ratio of the SOM pool than its donor (wood and litter) pools. Loss of $\mathrm{N}$ from ecosystems occurs through fire, denitrification, and leaching. The $\mathrm{N}$ lost due to fire is assumed to be emitted only in gaseous form, because the proportion of $\mathrm{N}$ retained in the residual ash is very small (Niemeyer et al., 2005; Qian et al., 2009). We consider the gaseous loss of inorganic $\mathrm{N}$ from denitrification but ignore the volatilization of $\mathrm{N}$ in the form of $\mathrm{NH}_{4}^{+}$. This flux usually occurs at a soil $\mathrm{pH}>8$ (Freney et al., 1983) or after application of $\mathrm{N}$ fertilizers (Yang et al., 2009), and $\mathrm{NH}_{3}$ emissions from soils under non-agricultural vegetation are relatively small globally (5 $\mathrm{Tg} \mathrm{N} \mathrm{yr}^{-1}$; Bouwman et al., 1997; Houlton et al., 2015), representing $<5 \%$ of total gaseous loss, so the omission of $\mathrm{NH}_{4}^{+} \mathrm{N}$ volatilization will not introduce large biases in our model for most regions. The dynamics of $\mathrm{N}$ in the pools are summarized by the differential equations in Appendix B.

\subsection{P cycle}

The $\mathrm{P}$ cycle, like the $\mathrm{N}$ cycle, is also coupled to the $\mathrm{C}$ cycle; the dynamics of $\mathrm{P}$ in the pools are described by the differential equations in Appendix $\mathrm{C}$. The external inputs of $\mathrm{P}$ to ecosystems include atmospheric $\mathrm{P}$ deposition and $\mathrm{P}$ released from P-bearing minerals by chemical weathering $\left(P_{\mathrm{d}}+P_{\mathrm{w}}\right.$ in Fig. 1). P from deposition and rock weathering enters the soil inorganic-P pool. The structure of the $\mathrm{P}$ cycle is the same as for the $\mathrm{N}$ cycle described above for foliar-P resorption, $\mathrm{P}$ released from the decomposition of litter and SOM and the immobilization of inorganic soil $\mathrm{P}$ by soil organisms. Inorganic $\mathrm{P}$, unlike inorganic $\mathrm{N}$, can be sorbed onto/into soil particles and subsequently become occluded. This form is assumed to be unavailable to plants. We modeled the flux from the labile soil $\mathrm{P}$ to occluded $\mathrm{P}$ with a constant rate. Loss pathways of $\mathrm{P}$ include fire, leaching, and conversion to occluded P. Notably, not all P mobilized by fire is emitted in gaseous form, but is partly retained in the residual ash (Niemeyer et al., 2005; Qian et al., 2009). We used a constant fraction of $75 \%$ (Niemeyer et al., 2005; Qian et al., 2009) to model the $\mathrm{P}$ retained in the residual ash during a fire, and this fraction of $\mathrm{P}$ enters the labile soil $\mathrm{P}$ pool. 


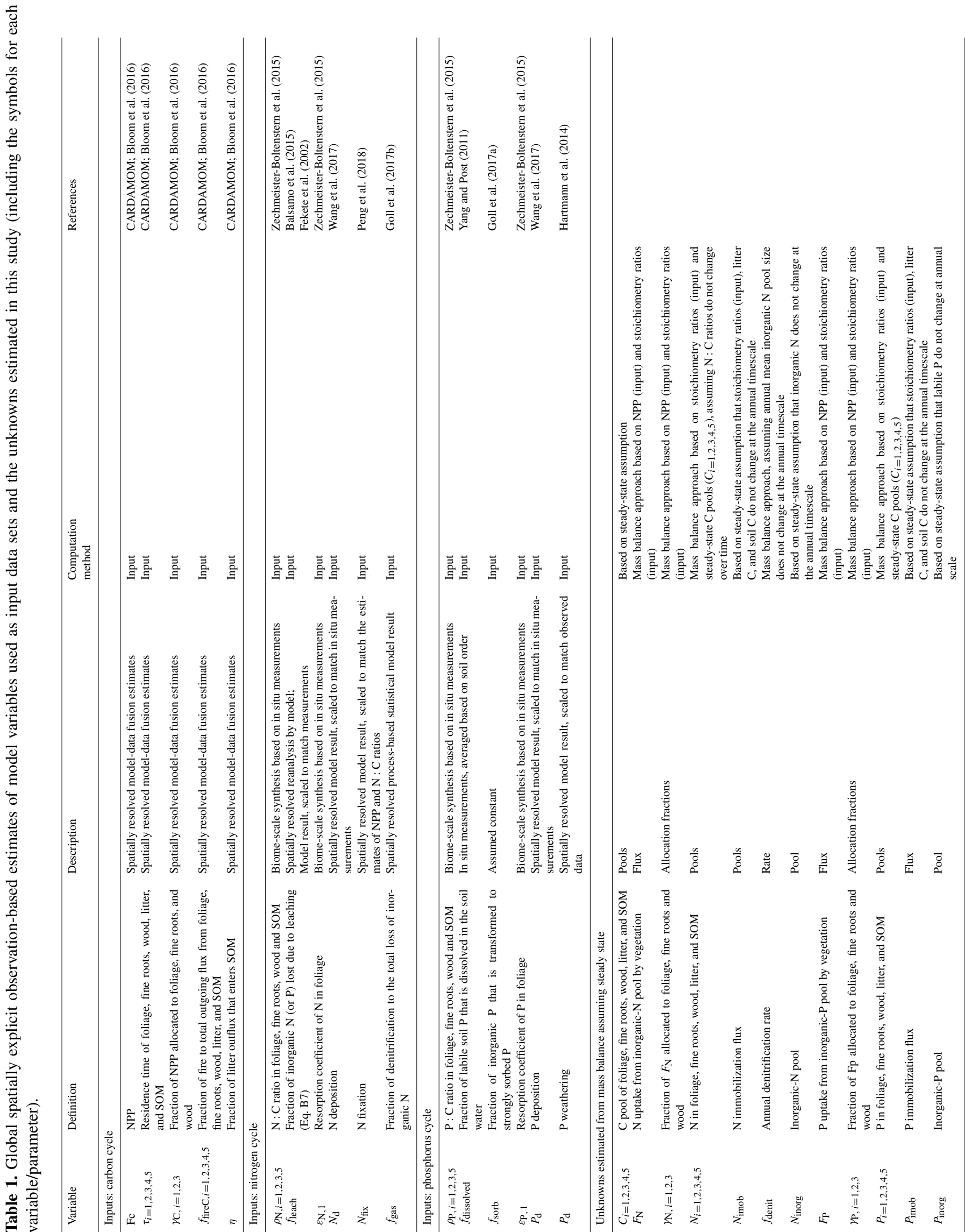




\section{Methods}

\subsection{Input data sets}

All parameters used as inputs for the calibration of GOLUMCNP are listed in Table 1. A steady state was assumed to infer remaining variables (also listed in Table 1). The estimates of fluxes and C-pool sizes were based on mass balances, and the estimates of $\mathrm{N}$ - and P-pool sizes were derived from the C-pool size and stoichiometric data (see below and Appendix E). We used the $\mathrm{C}$ fluxes and turnover times of $\mathrm{C}$ pools derived from CARDAMOM for the $\mathrm{C}$ cycle (Bloom et al., 2016), which offered a data-consistent analysis of terrestrial $\mathrm{C}$ cycling on a global $1^{\circ} \times 1^{\circ}$ grid for 20012010 by optimizing the DALEC 2 model parameters to match the state and process variables with the global observations of MODIS LAI (Myneni et al., 2015), soil C (Hiederer and Köchy, 2011), burned area (Giglio et al., 2013), and tropical biomass (Saatchi et al., 2011). Although the CARDAMOM data-driven analysis only reported the $\mathrm{C}$ pools and fluxes, the impacts of $\mathrm{N}$ and $\mathrm{P}$ on the $\mathrm{C}$ cycle have been implicitly reflected in CARDAMOM through the constraints by some of the observations. For example, the availability of $\mathrm{N}$ and/or $\mathrm{P}$ limits the growth of vegetation and thus the LAI observed (Klodd et al., 2016; Reich et al., 2010); the $\mathrm{N}$ and $\mathrm{P}$ contents in soil control the decomposition of soil $\mathrm{C}$ and thus the soil C pool observed (Manzoni et al., 2010). In this sense, it is appropriate to use the $\mathrm{C}$ cycle from CARDAMOM as inputs to estimate the pool and fluxes of $\mathrm{N}$ and $\mathrm{P}$.

Different indices have been used to describe nutrient cycling from different perspectives (soil, individual plant, vegetation, ecosystem, etc.; Augusto et al., 2017; Cleveland et al., 2013; Gill and Finzi, 2016). In this study, we focused on the openness, nutrient-use efficiencies and the residence time (Sect. 3.2), which are defined at the ecosystem scale and thus correspond to the scale at which DGVMs are typically defined. For the presentation of results, we distinguish seven biomes: tropical rainforests (TRF), temperate deciduous forests (TEDF), temperate coniferous forests (TECF), boreal coniferous forests (BOCF), tundra (TUN), tropical/ $\mathrm{C}_{4}$ grasslands (TRG), and temperate/ $\mathrm{C}_{3}$ grasslands (TEG). Note that similar empirical land-cover maps have been also used in previous studies to simulate $\mathrm{C}, \mathrm{N}$, and $\mathrm{P}$ cycles (Cleveland et al., 2013; Wang et al., 2010). We applied observed biome-specific $\mathrm{N}$ : C ratios for each pool from the synthesis by Zechmeister-Boltenstern et al. (2015).

We used the spatially explicit estimates of $\mathrm{N}$ deposition (Wang et al., 2017) for 2001-2010 (Fig. S2a), which were evaluated with globally distributed in situ measurements. The spatially explicit estimate for $\mathrm{N}$ fixation (Fig. S2b) was taken from the CABLE model simulation for 2001-2010 (Peng et al., 2018) with a $\mathrm{N}$ fixation model developed by Wang et al. (2007). The simulation result matches the relative abundance of $\mathrm{N}_{2}$-fixing legumes in different ecosystems. Globally, the $\mathrm{N}$ fixation is $116 \mathrm{Tg} \mathrm{N} \mathrm{yr}^{-1}$ and is within the range of empirical estimates (100-290 $\mathrm{Tg} \mathrm{N} \mathrm{yr}^{-1}$; Cleveland et al., 1999; Galloway et al., 2004), but larger than the estimate of $44 \mathrm{Tg} \mathrm{N} \mathrm{yr}^{-1}$ by Vitousek et al. (2013) for pre-industrial conditions. The large range $\left(44-290 \mathrm{Tg} \mathrm{N} \mathrm{yr}^{-1}\right)$ in the estimates of nitrogen fixation reflects both a paucity of measurements of $\mathrm{N}$ fixation, as well as incomplete understanding of the biophysical and biochemical controls on $\mathrm{N}$ fixation. And to our knowledge, CABLE simulation is the only product that has spatially explicit and processed-based estimates of $\mathrm{N}$ fixation, and is therefore used in this study. The resorption coefficients of leaves for the seven biomes were derived from the $\mathrm{N}: \mathrm{C}$ ratios of leaves and leaf litter reported by Zechmeister-Boltenstern et al. (2015). The rate of loss of inorganic $\mathrm{N}$ by leaching was determined from data for total soil moisture and runoff (Eq. B7). The spatially explicit estimate of total soil moisture was derived from the European Centre for Medium-Range Weather Forecasts (ECMWF) Interim Reanalysis (ERA-Interim/Land; Albergel et al., 2013; Balsamo et al., 2015). Gridded soil water content was provided in ERA-Interim/Land in four discretized layers until $2.89 \mathrm{~m}$ below ground, which is the soil depth we considered for the total soil moisture. Although some uncertainties exist at the grid scale, the large-scale patterns in soil moisture from ERA-Interim/Land are consistent with other products (Rötzer et al., 2015), enabling us to use it to represent the large-scale spatial gradients in soil water moisture. The global gridded estimate of runoff data was obtained from the Global Runoff Data Centre (GRDC, http://www.grdc.sr.unh.edu/, last access: 8 May 2017), which is constrained by observed river discharges from 663 stations globally. We used observation-based estimates of the fraction of $\mathrm{N}$ lost by denitrification to the total inorganic- $\mathrm{N}$ loss (denitrification + leaching) pathways (Goll et al., 2017b) to calibrate the denitrification-loss flux. This fraction of denitrification loss $\left(f_{\text {denit }}\right)$ was derived using a process-based statistical model fitted to global soil $\delta^{15} \mathrm{~N}$ data sets, based on the distinct ${ }^{15} \mathrm{~N}$ fractionation effect of denitrification versus loss from leaching (Bai et al., 2012; Houlton and Bai, 2009).

We constrained the $\mathrm{P}$ cycle using spatially explicit estimates by Wang et al. (2017) for P deposition for 2001-2010 (Fig. S3a). Spatially explicit estimates of $\mathrm{P}$ input from rock weathering (Fig. S3b) were derived from data for river discharge and the chemical composition of minerals by Hartmann et al. (2014). The P : C ratios and resorption coefficients for the seven biomes were obtained from ZechmeisterBoltenstern et al. (2015). Only a fraction of total inorganic $P$ can be lost by leaching, and this fraction of dissolved inorganic $\mathrm{P}$ in total labile $\mathrm{P}$ was derived based on the observations of Hedley soil $\mathrm{P}$ fractions as the resin-extractable $\mathrm{P}$ divided by total labile P reported by Yang and Post (2011) for the 12 USDA soil orders. The constant rate at which inorganic $\mathrm{P}$ becomes strongly sorbed ( $f_{\text {sorb }}$, Eq. C6) was fixed at $0.04 \mathrm{yr}^{-1}$ (Goll et al., 2017a).

Zechmeister-Boltenstern et al. (2015) only reported the stoichiometric ratios and the $\mathrm{N}$ and $\mathrm{P}$ resorption coefficients 


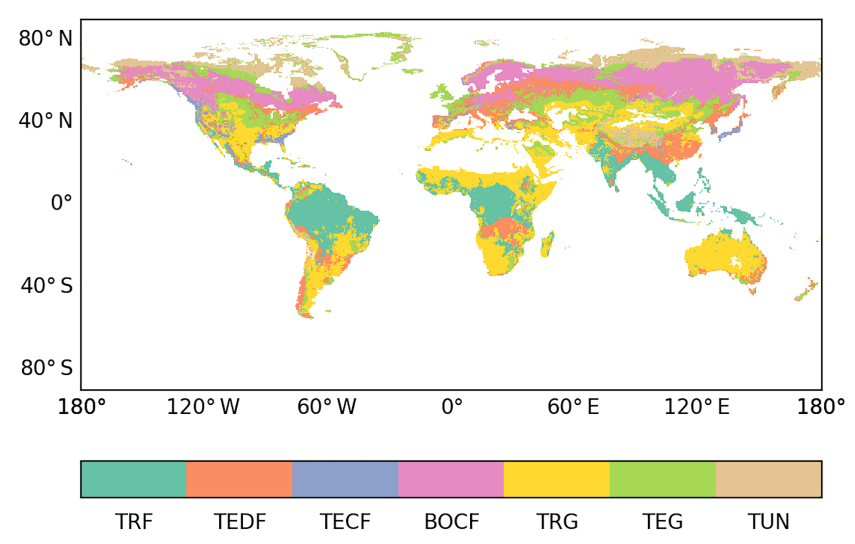

Figure 2. ESA CCI land-cover map classified into the seven large biomes for which average $\mathrm{N}: \mathrm{C}$ and $\mathrm{P}: \mathrm{C}$ ratios for each carbon pool are available at a $0.25^{\circ} \times 0.25^{\circ}$ resolution: tropical rainforests (TRF), temperate deciduous forests (TEDF), temperate coniferous forests (TECF), boreal coniferous forests (BOCF), tropical/ $\mathrm{C}_{4}$ grasslands (TRG), temperate/C $\mathrm{C}_{3}$ grasslands (TEG), and tundra (TUN).

for seven large non-agricultural biomes, but other input variables were grid-based products. A land-cover map was used to aggregate the grid-based C-cycle variables from Bloom et al. (2016) into the biomes used by Zechmeister-Boltenstern et al. (2015). The land-cover map was derived from the dominant land-cover type for each grid cell for the globe, excluding croplands, from the land-cover map of the Climate Change Initiative (LC_CCI) established by the European Space Agency (ESA; Bontemps et al., 2013) at $0.25^{\circ} \times 0.25^{\circ}$ resolution. Specifically, we used the 2010 map to classify all grid cells into one of the seven non-agricultural biomes of Zechmeister-Boltenstern et al. (2015; Fig. 2), following the methodology presented by Poulter et al. (2015).

\subsection{Model integration and output diagnostics}

We applied the model framework described in Sect. 2 to derive a data-driven estimate of steady-state $\mathrm{C}, \mathrm{N}$, and $\mathrm{P}$ cycling. A steady state indicates that annual mean input fluxes for all pools are assumed to be balanced by annual mean outgoing fluxes, with the annual mean outgoing fluxes from organic pools calculated as the quotient of the pool sizes to the corresponding turnover times. Assuming that all pool sizes were in a steady state, the left side of the equations in Appendices A-C (Eqs. A1-A5, B1-B6, and C1-C6) are all equal to zero. Adding the constraints in Appendix D (Eqs. D1D11), we derived a system with 28 equations and 28 unknown variables (Table 1), thereby defining all unknowns in GOLUM-CNP. The unknown variables were solved by applying the 33 global spatially explicit observation-based estimates listed in Table 1 in these equations (Appendix E). The set of equations of the GOLUM-CNP model was solved for each $0.25^{\circ} \times 0.25^{\circ}$ grid cell using biome-mean $\mathrm{N}: \mathrm{C}$ and
$\mathrm{P}: \mathrm{C}$ stoichiometric ratios, grid-cell specific values of $\mathrm{C}$ variables from Bloom et al. (2016) and the gridded external Nand P-input and -output fields described above. In this computation, some processes were only solved by mass balance and the steady-state assumption instead of explicitly being calibrated. For example, we did not explicitly simulate various pathways of $\mathrm{N}$ and $\mathrm{P}$ mineralization and immobilization. The $\mathrm{N}$ and $\mathrm{P}$ mineralization fluxes are computed as the product of the decomposition of $\mathrm{C}$ in litter and SOM and their respective stoichiometries, and $\mathrm{N}$ and $\mathrm{P}$ immobilization fluxes are computed by mass balance to match the higher $\mathrm{N}: \mathrm{C}$ and $\mathrm{P}: \mathrm{C}$ ratios in the SOM pool compared to the ratios in inputs to SOM from wood and litter decomposition. For instance, $\mathrm{N}$ and $\mathrm{P}$ mineralization were computed as the difference between nutrient demand of vegetation and the sum of external inputs and resorption in Cleveland et al. (2013, Eqs. S5 and S6), assuming that the nutrients available to plants in soil do not change significantly at current stage. Some variables were computed by mass balance and do not rely on steady state assumption, e.g., the uptake of $\mathrm{N}\left(F_{\mathrm{N}}\right)$ and $\mathrm{P}\left(F_{\mathrm{P}}\right)$ by plants (Table 1). Such computations based on mass balance and steady-state assumptions allow us to have a diagnostic modeling framework, but at the same time capture observations of carbon fluxes, pools, and pool stoichiometries.

The inputs of the $\mathrm{C}$ cycle from the original CARDAMOM data set were provided as probability distributions, while other data sets were provided only as mean values. In this study, we compute the GOLUM-CNP using the mean values of all the input data sets to represent the mean behavior of the $\mathrm{C}, \mathrm{N}$, and $\mathrm{P}$ cycling.

We present the $\mathrm{C}, \mathrm{N}$, and $\mathrm{P}$ pools and the fluxes between them for each biome. We also aggregated the results at the global scale and compared them with previous studies. We calculated some ecologically relevant quantities from the GOLUM-CNP output. We defined the "openness" of $\mathrm{N}$ and $\mathrm{P}$ cycles as $\mathrm{NO}$ and $\mathrm{PO}$ that were calculated as the ratio of nutrient inputs $\left(I_{x}, X \in\{\mathrm{N}, \mathrm{P}\}\right)$, taken as the sum of deposition $\left(N_{\mathrm{d}}\right)$ and biological fixation $\left(N_{\mathrm{fix}}\right)$ for $\mathrm{N}$ and as the sum of deposition $\left(P_{\mathrm{d}}\right)$ and release from rock weathering $\left(P_{\mathrm{w}}\right)$ for $\mathrm{P}$, over the amount of nutrients used in NPP, taken as the sum of uptake from inorganic $\mathrm{N}$ or labile soil $\mathrm{P}$ pools $\left(F_{x}\right.$, $X \in\{\mathrm{N}, \mathrm{P}\}$ ) and resorbed nutrients $\left(\mathrm{RSB}_{x}, X \in\{\mathrm{N}, \mathrm{P}\}\right)$, leading to

$X \mathrm{O}=\frac{I_{x}}{F_{x}+\mathrm{RSB}_{x}}$.

The openness quantifies how much nutrients are from external inputs, which is similar but not strictly equal to the "proportion of new NPP fueled by new nutrient inputs". In general, the "openness" used in this study and the "proportion of new NPP fueled by new nutrient inputs" in Cleveland et al. (2013) both quantify the ratios between fluxes that are related to external inputs and the "total" fluxes, but openness used in this study was defined from nutrient cycles, while the index used in Cleveland et al. (2013) was defined from NPP- 
carbon. In addition, the practical computation of the openness in this study is slightly different from that of Cleveland et al. (2013), which was quantitatively compared in the Supplement Sect. S1.

The mean residence time of $\mathrm{N}$ and $\mathrm{P}$ for the entire ecosystem $\left(\tau_{X, \text { eco }}, X \in\{t \mathrm{~N}, \mathrm{P}\}\right)$ was defined as the ratio of total modeled pool mass (including plant, litter, SOM, and inorganic pools) to all outgoing fluxes. The sum of all steadystate outgoing fluxes was set equal to the sum of external input fluxes, so we calculated the mean residence time of $\mathrm{N}$ and $\mathrm{P}$ by

$$
\begin{aligned}
\tau_{\mathrm{N}, \mathrm{eco}}= & \frac{\sum_{i=1}^{5} N_{i}+N_{\text {inorg }}}{N_{\mathrm{d}}+N_{\text {fix }}}, \\
\tau_{\mathrm{P}, \mathrm{eco}}= & \frac{\sum_{i=1}^{5} P_{i}+P_{\text {inorg }}}{P_{\mathrm{d}}+P_{\mathrm{w}}} .
\end{aligned}
$$

The nutrient-use efficiencies (NUE and PUE) were defined by

$\mathrm{XUE}=\frac{\mathrm{GPP}}{F_{x}}$,

where $F_{x}(X \in\{\mathrm{N}, \mathrm{P}\})$ is the annual uptake of inorganic soil $\mathrm{N}$ or $\mathrm{P}$ by plants, and $f_{\mathrm{NPP}}$ is the ratio of NPP to gross primary production (GPP) from CARDAMOM. Our model used NPP as the input C flux for ecosystems, but we used GPP instead of NPP in Eq. (3) to calculate XUE for comparing with the estimates based on in situ measurements by Gill and Finzi (2016), which were also based on GPP. We thus used $f_{\mathrm{NPP}}$ only as an external variable in our modeling framework, and $f_{\mathrm{NPP}}$ was not targeted when evaluating the sensitivities and uncertainties in the results (see below).

We tested the steady-state sensitivity (SS) of the model results to the observational data sets (inputs of the model listed in Table 1) by linearizing the GOLUM-CNP model and its solver for calculating the first-order partial derivative of all outputs relative to each input parameter:

$\mathrm{SS}=\partial \boldsymbol{O} / \partial \boldsymbol{I}(4)$,

where $\boldsymbol{I}$ is the vector of the input variables, and $\boldsymbol{O}$ is the vector of the output variables. This approach directly provided a sensitivity matrix, which allowed us to test the effect of the accuracy of the measurement of each input variable on the model results for the $\mathrm{N}$ and $\mathrm{P}$ cycles. This method was similar to the "one-at-a-time" (OAT) approach used for sensitivity analysis in previous $\mathrm{C}-\mathrm{N}$ coupled modeling studies (Orwin et al., 2011; Shi et al., 2016; Zaehle and Friend, 2010) but did not require running simulations by changing the inputs one at a time. This approach did not fully explore the possible range of values for a given parameter, but provided comparable SS values for different parameters, which is useful when the full uncertainty ranges of some parameters are unknown, e.g., uncertainty due to the inconsistent definitions between the measured pools in the real world and the conceptual pools in the model, or the large uncertainty due to sparse observations for some biomes. The input parameters had distinct magnitudes (and units), so we used the relative sensitivities, e.g., $\mathrm{SS}=\partial \boldsymbol{O} / \boldsymbol{O} /(\partial \boldsymbol{I} / \boldsymbol{I})$, to compare the sensitivities to different model inputs. For the sensitivity analysis, an SS of 1 indicates that a 1\% increase (or decrease) in a model input produces a $1 \%$ increase (or decrease) in the model output, and an SS of -0.5 indicates that a $1 \%$ increase (or decrease) in the model input produces a $-0.5 \%$ decrease (or increase) in the model output. The results of this sensitivity analysis could be further used to investigate the sources of uncertainty in the outputs and to evaluate variances in the model outputs using error propagation:

$$
\begin{aligned}
& \boldsymbol{\varepsilon}_{\boldsymbol{O}, i}=\frac{\partial \boldsymbol{O}}{\partial \boldsymbol{I}_{i}} \boldsymbol{\varepsilon}_{\boldsymbol{I}, i}, \\
& \boldsymbol{\varepsilon}_{\boldsymbol{O}}=\sum_{i=1}^{n} \frac{\partial}{\partial \boldsymbol{O}} \boldsymbol{\varepsilon}_{\boldsymbol{I}, i}, \\
& \Sigma_{\boldsymbol{O}}=E\left(\boldsymbol{\varepsilon}_{\boldsymbol{O}}^{T} \boldsymbol{\varepsilon}_{\boldsymbol{O}}\right),
\end{aligned}
$$

where $\boldsymbol{\varepsilon}_{\boldsymbol{I}, i}$ is the error in the $i$ th input data, $\boldsymbol{\varepsilon}_{\boldsymbol{O}, i}$ is the error propagated from the error in input $i, \varepsilon_{\boldsymbol{O}}$ is the error that accounts for errors in all input data, $E$ represents the expectation of a variable and $\boldsymbol{\Sigma}_{\boldsymbol{O}}$ is the covariance matrix whose diagonal entries are the variances in the outputs.

\subsection{Adjustments of the CARDAMOM C cycle}

In CARDAMOM, there was no explicit separation between forests and grasslands and CARDAMOM provided low woody biomass in grassland-dominated regions (Saatchi et al., 2011; Williams et al., 2013), while grasslands are considered as biomes and have no woody biomass in GOLUMCNP. In order to represent the grassland biomes in GOLUMCNP and to conserve the global NPP from CARDAMOM, we approximated the $\mathrm{C}$-cycle state of the non-forest biomes (TRG, TEG, and TUN) by partitioning half of CARDAMOM woody NPP to foliar NPP and half to fine roots, in order to better represent grassland $\mathrm{C}, \mathrm{N}$, and $\mathrm{P}$ cycling across these biomes.

The CARDAMOM terrestrial $\mathrm{C}$ analysis did not assume steady states. Our goal, however, was to describe the steady states of $\mathrm{C}, \mathrm{N}$, and $\mathrm{P}$ cycling, because few global long-term observations associated with $\mathrm{N}$ and $\mathrm{P}$ were available to constrain the model. We recalculated the $\mathrm{C}$ cycle based on a subset of the CARDAMOM results. Specifically, we used NPP and turnover times of the $\mathrm{C}$ pools for 2001-2010 (Table 1) and recalculated the steady-state sizes of these pools and the transfers of $\mathrm{C}$ between the pools represented in Fig. 1, solving Eqs. (A1)-(A5) with their left sides as zeros. This steadystate transformation of the CARDAMOM C cycle is assessed in Sect. 4.1. 


\section{Results}

\subsection{Steady state $\mathrm{C}$ cycle}

Table 2 shows the global C-pool sizes and main fluxes of the steady-state $\mathrm{C}$ cycle transformed from CARDAMOM under the climate conditions of 2001-2010. Although the steadystate $\mathrm{C}$ stocks do not exactly represent the $\mathrm{C}$ stocks at the present day, the differences between the steady-state transformed pool sizes and the original non-steady-state CARDAMOM results were within $10 \%$ for most $\mathrm{C}$ pools and fluxes. The largest differences were for biomass (foliar, fineroot, and wood) pools. The larger foliar and fine-root pools in the steady-state GOLUM-CNP model were due to adjustments done for grass-dominated grid cells for which CARDAMOM provided some wood growth inconsistent with the biome distribution used in GOLUM-CNP. In these cases, we allocated wood growth from CARDAMOM into growth of fine root and foliage. These pools in GOLUM-CNP, however, remained within the $[5,95$ th] percentile range of the original CARDAMOM values. The pool size for global woody biomass was $37 \%$ smaller in the steady-state model (469 Pg) than the original CARDAMOM results but remained within its inter-quartile range $(364-984 \mathrm{Pg})$. The differences between the gridded maps from original CARDAMOM and GOLUM-CNP are shown in Fig. S1 in the Supplement. The steady-state transformed C stocks in biomass, litter, and SOM were within the 25th and 75th percentiles of the original CARDAMOM results at more than $90 \%$ of forest grid cells, indicating that our steady-state transformed $\mathrm{C}$ stocks are close to the actual $\mathrm{C}$ stocks of the present day, given the large uncertainties in the state-of-the-art estimates. Due to the adjustment made for the grass-dominated grid cells (see above), the $\mathrm{C}$ pools for grassland differ more strongly than the forest-dominated area from the original CARDAMOM.

\subsection{Steady-state nutrient stocks and fluxes}

Figures 3 and 4 summarize the stocks and fluxes of $\mathrm{N}$ and $\mathrm{P}$ for the seven biomes and for the globe. The uptake fluxes of $\mathrm{N}$ and $\mathrm{P}$ were largest for tropical forests, mainly driven by the large NPP of this biome. Rates of N and P uptake were lower for temperate and boreal forests than tropical forests and for non-forest biomes than forests. The pool sizes of $\mathrm{N}$ and $\mathrm{P}$ in plants tended to decrease from tropical to boreal regions, following the C-pool sizes and their observed stoichiometries. Conversely, $\mathrm{N}$ and $\mathrm{P}$ contents in litter were larger for boreal forests, temperate grasslands, and tundra ecosystems than the other biomes, mainly due to a longer turnover of the litter pool in these biomes. The N-pool size of SOM was also larger in boreal forests, temperate grasslands, and tundra than the other biomes. The P-pool size in SOM, however, was smaller for boreal forests and tundra than the other biomes, consistent with the differences between the $\mathrm{N}: \mathrm{C}$ and $\mathrm{P}: \mathrm{C}$ ratios of boreal biomes compared to other biomes (Table S1).
Inorganic $\mathrm{N}$ and labile soil $\mathrm{P}$ pools and leaching rates of $\mathrm{N}$ and $\mathrm{P}$ were higher in tropical forests, where runoff was higher than in the other biomes. Semi-arid tropical grassland (TRG) had high losses of $\mathrm{N}$ and $\mathrm{P}$ by fire and a low loss from leaching. The internal $\mathrm{N}$ and $\mathrm{P}$ fluxes within ecosystems were usually much larger than the external input fluxes and the output fluxes for all biomes, highlighting the dominant role of internal cycling of $\mathrm{N}$ and $\mathrm{P}$, which differed from $\mathrm{C}$ cycles where NPP and losses by respiration were larger than any internal C flux.

Here we compared the estimates of $\mathrm{N}$ and $\mathrm{P}$ stocks for global terrestrial biosphere with other studies. Our estimate of $\mathrm{N}$ in plants $(3.9 \mathrm{Pg} \mathrm{N})$ was close to the estimate modeled by Zaehle et al. (2013, 3.5 Pg N), and was within the range of other studies, from $1.8 \mathrm{Pg} \mathrm{N}$ by Yang et al. (2009) to $6.57 \mathrm{Pg} \mathrm{N}$ by Wang et al. (2010). Our estimate of $\mathrm{N}$ in litter and SOM was lower than the estimate of $65 \mathrm{Pg} \mathrm{N}$ by XuRi and Prentice (2008) and Yang et al. (2009), but smaller than the estimate of $126 \mathrm{Pg} \mathrm{N}$ by Wang et al. (2010). Our estimate of the $\mathrm{P}$ mass in plants $(0.17 \mathrm{Pg} \mathrm{P})$ was smaller than the estimates modeled by Wang et al. (2010, 0.39 Pg P) and Goll et al. (2012, 0.23 Pg P). Our estimate of the litter P mass $(0.03 \mathrm{Pg} \mathrm{P})$ was similar to the estimate of $0.04 \mathrm{Pg} \mathrm{P}$ by the CABLE model (Wang et al., 2010) but was 2-fold lower than the estimate $(0.08 \mathrm{Pg}$ P) modeled by Goll et al. (2012).

The rate of total $\mathrm{N}$ input (deposition and fixation) aggregated to the global scale was $0.19 \mathrm{Pg} \mathrm{N} \mathrm{yr}^{-1}$ and equated (by construction) to the steady-state rate of total $\mathrm{N}$ loss. Total $\mathrm{N}$ uptake by plants was $0.68 \mathrm{Pg} \mathrm{N} \mathrm{yr}^{-1}$. Our estimate of $\mathrm{N}$ denitrification was $0.10 \mathrm{Pg} \mathrm{N} \mathrm{yr}^{-1}$, consistent with the independent estimate of global soil denitrification of $0.12 \mathrm{Pg} \mathrm{N} \mathrm{yr}^{-1}$ by Seitzinger et al. (2006) and within the range reported by other studies, from $0.04 \mathrm{Pg} \mathrm{N} \mathrm{yr}^{-1}$ (Houlton and Bai, 2009) to $0.29 \mathrm{Pg} \mathrm{N} \mathrm{yr}^{-1}$ (Galloway et al., 2013). The global loss of $\mathrm{N}$ was $0.05 \mathrm{Pg}$ from fire and $0.04 \mathrm{Pg} \mathrm{N} \mathrm{yr}^{-1}$ from leaching, the latter being similar to the independent estimates by Galloway et al. $(2004,2013)$ of $0.013-0.18 \mathrm{Pg} \mathrm{N} \mathrm{yr}^{-1}$ and by Houlton and Bai (2009) of $0.09 \mathrm{Pg} \mathrm{N} \mathrm{yr}^{-1}$. Globally, the loss of $\mathrm{N}$ by fire accounted for $26 \%$ of the total $\mathrm{N}$ loss. The total input of $\mathrm{P}$ to the terrestrial ecosystem was $0.007 \mathrm{Pg} \mathrm{Pyr}^{-1}$, $86 \%$ from deposition (range from $71 \%$ for BOCF to $92 \%$ for TRG); only a small fraction was from rock weathering (ranging from $8 \%$ to $29 \%$ across biomes). The loss of $\mathrm{P}$ is mainly from leaching and the loss by fire accounted for only $18 \%$ of the total P loss, much smaller than the fraction for $\mathrm{N}$.

\subsection{Implications for ecological research}

Figure 5 shows the latitudinal distribution of foliar $\mathrm{N}$ : $\mathrm{P}$ ratios in our model. This result reflects the distribution of the seven biomes and respective $\mathrm{C}: \mathrm{N}$ and $\mathrm{C}: \mathrm{P}$ ratios - both of which are prescribed here. Foliar $\mathrm{N}: \mathrm{P}$ ratios decreased on average from low to high latitudes. Estimates from previous studies also followed this trend (Kerkhoff et al., 2005; McGroddy et al., 2004; Reich and Oleksyn, 2004) based on fo- 
Table 2. Global annual mean C-pool sizes, NPP and heterotrophic-respiration fluxes in the C-cycle model assuming steady states under the climate conditions of 2001-2010, compared to the means and percentile ranges from the original CARDAMOM results during 2001-2010.

\begin{tabular}{|c|c|c|c|c|c|c|}
\hline & \multirow{2}{*}{ This study } & \multicolumn{5}{|c|}{ Original CARDAMOM } \\
\hline & & $\begin{array}{l}5 \text { th } \\
\text { percentile }\end{array}$ & $\begin{array}{r}25 \text { th } \\
\text { percentile }\end{array}$ & Mean & $\begin{array}{r}75 \text { th } \\
\text { percentile }\end{array}$ & $\begin{array}{l}\text { 95th } \\
\text { percentile }\end{array}$ \\
\hline Foliage-pool size (Pg C) & 23 & 3.2 & 7 & 15 & 21 & 34 \\
\hline Fine-root-pool size (Pg C) & 27 & 1.9 & 5 & 18 & 25 & 56 \\
\hline Wood-pool size (Pg C) & 493 & 193 & 364 & 755 & 984 & 1850 \\
\hline Litter-pool size (Pg C) & 20 & 1.3 & 4 & 22 & 26 & 88 \\
\hline SOM-pool size (Pg C) & 1421 & 749 & 1100 & 1557 & 1882 & 2771 \\
\hline $\mathrm{NPP}\left(\mathrm{Pg} \mathrm{C} \mathrm{yr}^{-1}\right)$ & 52.5 & not given & 39 & 52 & 63 & not given \\
\hline Fire $\left(\mathrm{PgC}_{\mathrm{yr}}{ }^{-1}\right)$ & 1.5 & not given & 1.3 & 1.7 & 2.0 & not given \\
\hline Heterotrophic respiration $\left(\mathrm{Pg} \mathrm{C} \mathrm{yr}^{-1}\right)$ & 51 & not given & 37 & 54 & 67 & not given \\
\hline
\end{tabular}

liar measurements. The mean $\mathrm{N}: \mathrm{P}$ ratios in our study were in the middle of the range of observations for all latitudes. The results of GOLUM-CNP better indicated the high $\mathrm{N}$ : $\mathrm{P}$ ratios between 20 and $40^{\circ}$, where grassland is the dominant biome, than the monotonic regressions (colored lines in Fig. 4) derived by Reich and Oleksyn (2004) and Kerkhoff et al. (2005) for foliar data, implying that the use of stoichiometries at the scale of large biomes can identify the general features of the spatial gradients of $\mathrm{N}$ and $\mathrm{P}$ cycling.

Figure $6 \mathrm{a}$ and $\mathrm{b}$ show the distribution of the openness (defined as the ratio of new nutrient inputs to the total plant uptake of nutrients, Sect. 3.2) for $\mathrm{N}$ and $\mathrm{P}$ in different ecosystems and Fig. S4a and b show the gridded maps of these indices. New $\mathrm{N}$ in forest ecosystems (sum of deposition and biological fixation) accounted for $10 \%$ (BOCF) to $51 \%$ (TECF) of the total plant uptake of $\mathrm{N}$, and new $\mathrm{P}$ (due to deposition and rock weathering) accounted for only $3.5 \%$ (BOCF) to $15 \%$ (TRF) of the total plant uptake of P. The openness of both $\mathrm{N}$ and $\mathrm{P}$ in grassland ecosystems decreased from the tropics to high latitudes. The residence times of $\mathrm{N}$ and $\mathrm{P}$ in ecosystems were much longer than those of $\mathrm{C}$ (Table S2) and decreased from the tropics to boreal areas (Figs. 5c, d, S5a, and b).

The openness and residence times of $\mathrm{N}$ and $\mathrm{P}$ together allow us to assess the relative importance of external inputs and internal cycling to support plant growth. For example, TECF are characterized by a more open $\mathrm{N}$ cycle and a longer $\mathrm{N}$ residence time compared to TRF. The difference in the openness of the $\mathrm{N}$ cycle indicates that the TECF intends to invest more resources to obtain $\mathrm{N}$ from external inputs than TRF. The differences in residence times indicate that $\mathrm{N}$ is more efficiently conserved within the ecosystem in TECF compared to TRF, and such a conservation within ecosystems is primarily driven by differences in the turnover of dead organic matter (Fig. 3). The P cycle is less open than the $\mathrm{N}$ cycle in all ecosystems, highlighting the importance of ecosystem $\mathrm{P}$ recycling within ecosystems to support plant growth.
Figure 7 shows the diagnosed nutrient-use efficiencies from GOLUM-CNP outputs for the seven biomes and Fig. S6a and b show the gridded maps of nutrient-use efficiencies. Among forest biomes, tropical forest had the lowest NUE and the highest PUE compared to other forest biomes (Fig. 7a), consistent with the higher $\mathrm{P}$ and lower $\mathrm{N}$ stresses in tropical ecosystems (Gill and Finzi, 2016; Reich and Oleksyn, 2004). The values of NUE and PUE were similar to each other for TEDF, TECF, and BOCF. Nutrient-use efficiencies were about 3-fold lower for non-forest biomes (Fig. 7b) than forest biomes, and both NUE and PUE decreased from tropical/ $\mathrm{C}_{4}$ grassland to tundra.

\subsection{Sensitivity analysis}

Figure 8 shows the mean sensitivity of the nutrient-uptake fluxes $\left(F_{\mathrm{N}}\right.$ and $F_{\mathrm{P}}$ ), nutrient-use efficiencies (NUE and PUE), pool sizes of inorganic $\mathrm{N}$ and $\mathrm{P}$ ( $N_{\text {inorg }}$ and $\left.P_{\text {inorg }}\right), \mathrm{N}$ and $\mathrm{P}$ openness, residence times of $\mathrm{N}$ and $\mathrm{P}$ in the ecosystem ( $\tau_{\mathrm{N}, \text { eco }}$ and $\tau_{\mathrm{P}, \mathrm{eco}}$ ), and residence times of $\mathrm{N}$ and $\mathrm{P}$ in plants ( $\tau_{\mathrm{N} \text {,plant }}$ and $\tau_{\mathrm{P} \text {,plant }}$ ) to the input variables for the tropicalrainforest biome (TRF). The sensitivities were similar for the other biomes (Figs. S7-S12). The uptake of nutrients in GOLUM-CNP was determined by NPP, NPP-allocation fractions, observation-based nutrient to $\mathrm{C}$ ratios and resorption coefficients (Eqs. E7 and E18); so N uptake for tropical forest (Fig. 8a) was highly sensitive to NPP (1.0), NPP-allocation fractions (0.3), and the $\mathrm{N}: \mathrm{C}$ ratio (0.4) of the woody pool, and $\mathrm{P}$ uptake was sensitive to NPP (1.0) and foliar variables $\left(0.5\right.$ for $\gamma_{\mathrm{C}, 1}$ and 0.5 for $\rho_{\mathrm{P}, 1}$; see Table 1 for the definition of these variables). The nutrient-use efficiencies, defined in Eq. (1) as the ratio between GPP and the nutrient-uptake fluxes (Eq. 3), were negatively sensitive to the input variables mentioned above. Estimates of the openness of $\mathrm{N}$ and $\mathrm{P}$ were sensitive to input fluxes, NPP, NPP-allocation fractions, and stoichiometric inputs. The residence times of nutrients in the ecosystem were influenced by variables affecting vegetation growth (e.g., NPP and allocation fractions of NPP) and 
(a) TRF

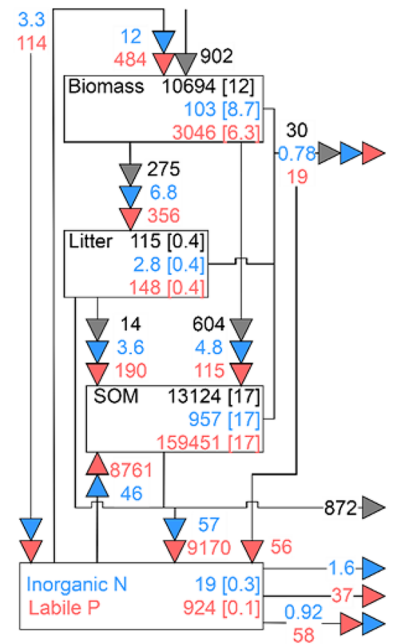

(d) BOCF

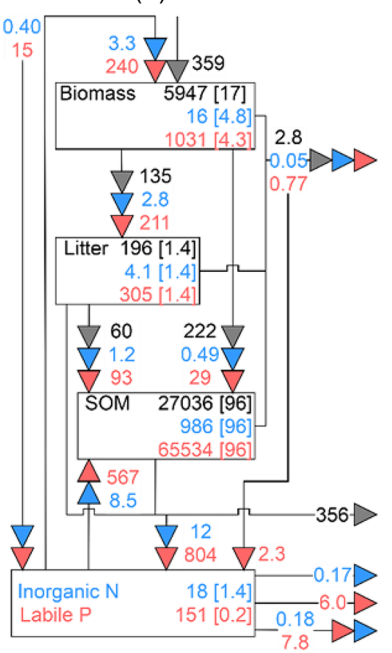

(g) TUN

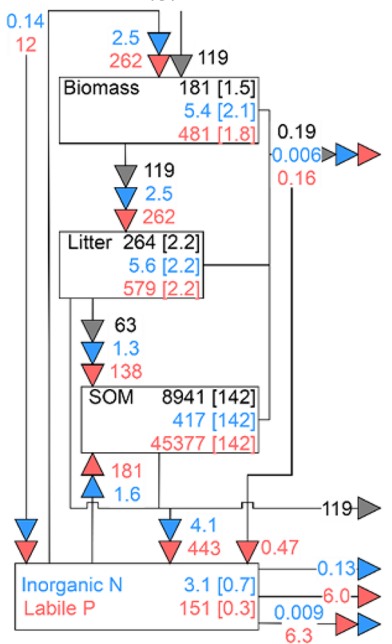

(b) TEDF

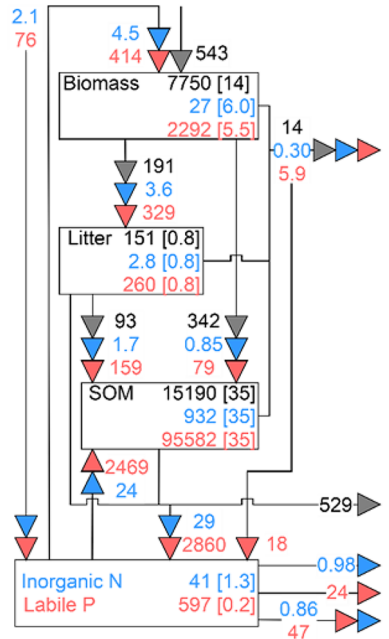

(e) TRG

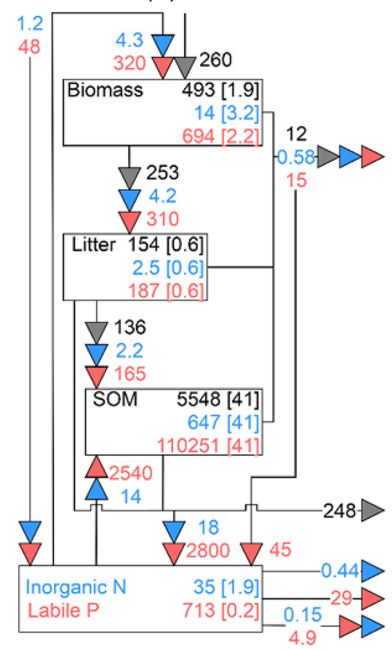

(h) Globe

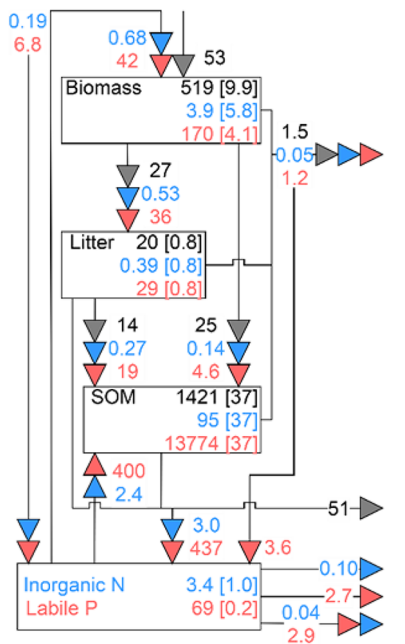

(c) TECF

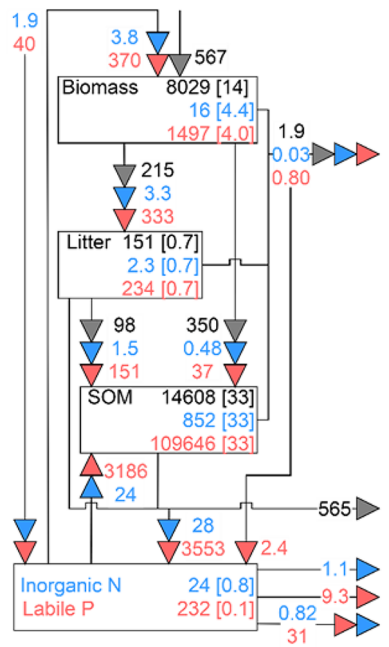

(f) TEG

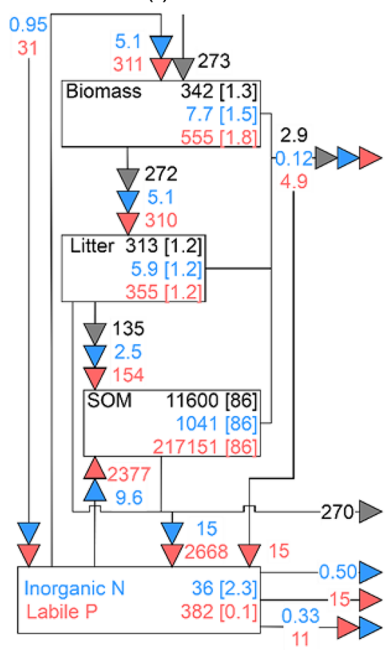

Units: (a)-(g)

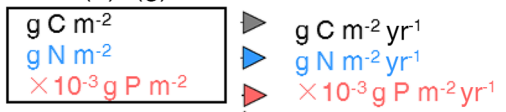

Units: (h)

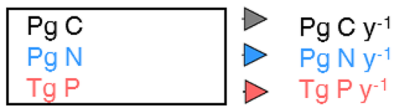

Figure 3. Fluxes (numbers along arrows), mean residence times (in parentheses), and pool sizes of the $\mathrm{N}$ (blue) and $\mathrm{P}$ (red) cycles in the terrestrial biosphere at steady state for the large biomes (a-g) and the globe (h). The targeted biomes are tropical rainforests (TRF, a), temperate deciduous forests (TEDF, $\mathbf{b}$ ), temperate coniferous forests (TECF, $\mathbf{c}$ ), boreal coniferous forests (BOCF, $\mathbf{d}$ ), tropical/ $\mathrm{C}_{4}$ grasslands (TRG, e), temperate/ $\mathrm{C}_{3}$ grasslands (TEG, $\mathbf{f}$ ), and tundra (TUN, $\mathbf{g}$ ). 

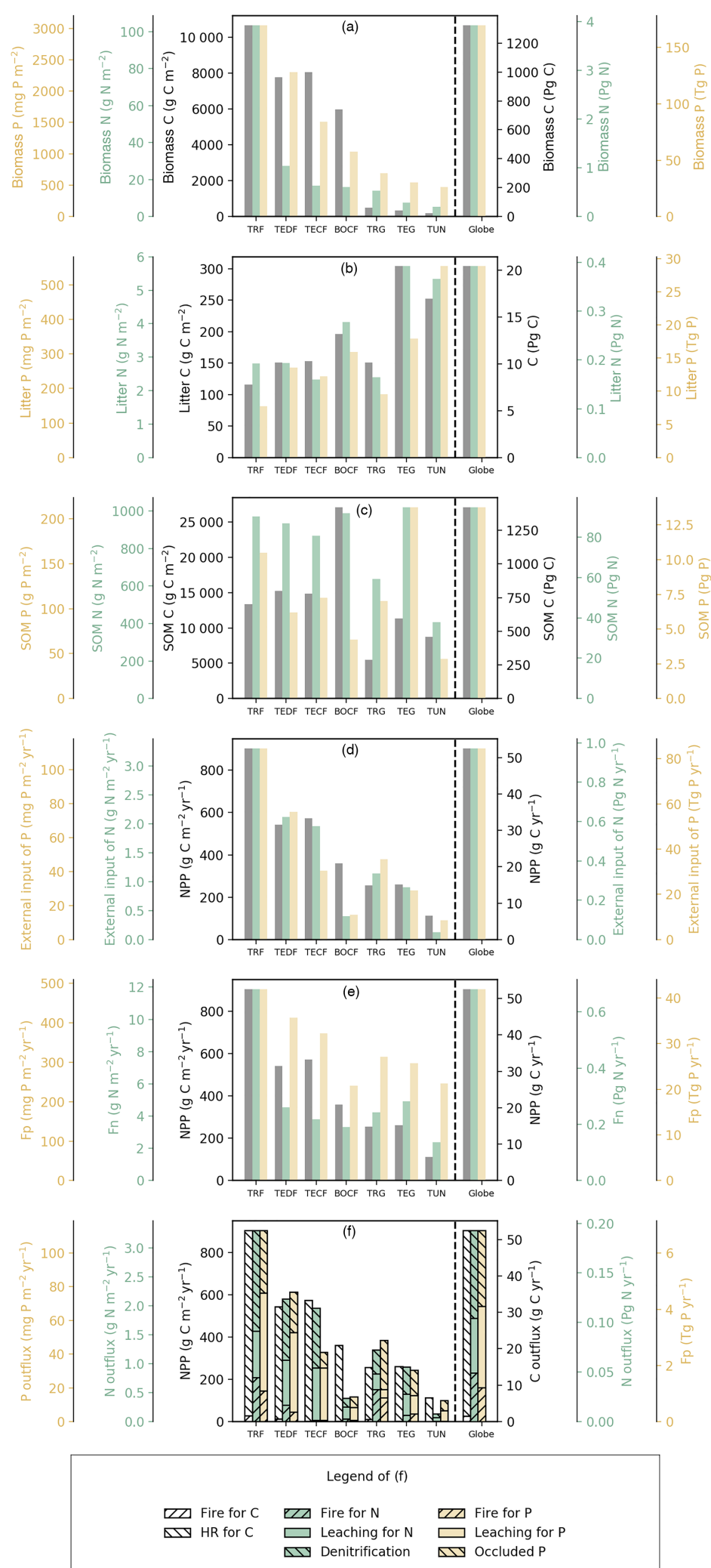

Figure 4. Pool sizes and fluxes of $\mathrm{C}$ (black), N (green), and $\mathrm{P}$ (yellow) computed from GOLUM-CNP. 


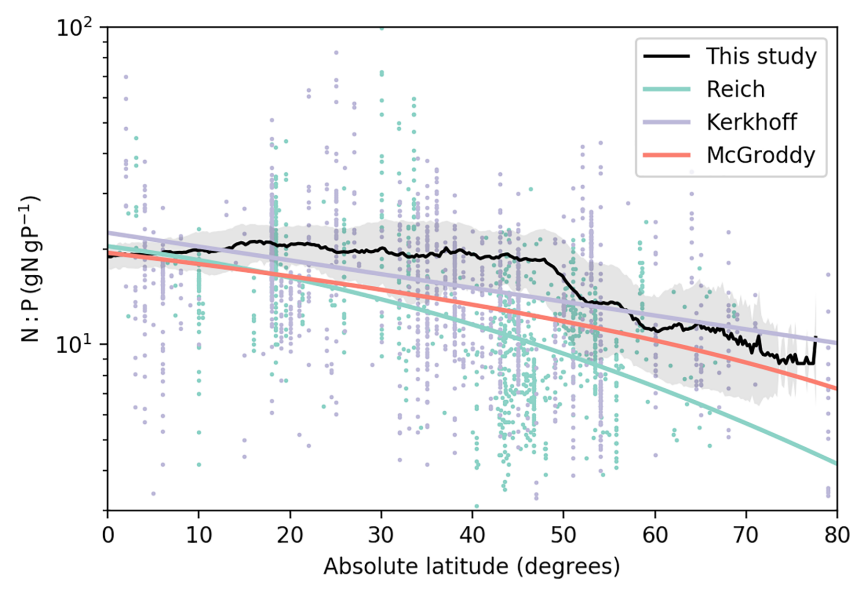

Figure 5. Relationship between foliar $\mathrm{N}: \mathrm{P}$ ratios $\left(\mathrm{gN} \mathrm{gP}^{-1}\right)$ and absolute latitude. The black line is the mean $\mathrm{N}: \mathrm{P}$ ratios from this study, and the shaded area is the one-sigma standard deviation of the $\mathrm{N}$ : $\mathrm{P}$ ratios for a specific latitude. Colored lines are the regression trends of foliar $\mathrm{N}: \mathrm{P}$ ratios as a function of absolute latitude from Reich and Oleksyn (2004; green), Kerkhoff et al. (2005; blue), and McGroddy et al. (2004; red). Dots are the raw data that Reich and Oleksyn (2004; green) and Kerkhoff et al. (2005; blue) used to derive their regression trends.

those affecting inputs (e.g., deposition, $\mathrm{N}$ fixation, and $\mathrm{P}$ release from rock weathering) to about equal extent. They were also very sensitive to variables related to soil, e.g., the $\mathrm{N}: \mathrm{C}$ and $\mathrm{P}: \mathrm{C}$ ratios in soil and residence times of soil. This reflects the large stocks of $\mathrm{C}$ and nutrients in soils than in the vegetation. The residence times of nutrients in whole plants ( $\tau_{\mathrm{N}, \text { plant }}$ and $\tau_{\mathrm{P} \text {,plant }}$ ) were more sensitive to the variables affecting woody biomass than those affecting foliage and fine roots. The sensitivity of residence times in the ecosystem and whole plants suggested that the nutrient cycling in the terrestrial biosphere was primarily determined by the largest pools.

\section{Discussion}

We developed a new observation-based modeling framework of global terrestrial $\mathrm{N}$ and $\mathrm{P}$ cycling built on a data-driven $\mathrm{C}$ cycle model and observed $\mathrm{N}: \mathrm{C}$ and $\mathrm{P}: \mathrm{C}$ stoichiometric ratios in different pools spatially averaged at the scale of large biomes and observation-based estimates of the external input and output fluxes of $\mathrm{N}$ and $\mathrm{P}$. This model was then used to estimate the pool sizes and fluxes in $\mathrm{N}$ and $\mathrm{P}$ cycles and indicators of the coupling between nutrient and $\mathrm{C}$ cycling, including nutrient openness, residence times in ecosystems, and nutrient-use efficiencies. The data-driven estimates of steady-state global $\mathrm{C}, \mathrm{N}$, and $\mathrm{P}$ cycles are the first that are fully consistent with a large set of global observation-based data sets, under the condition of current climate, deposition, and $\mathrm{CO}_{2}$ concentration. The indicators for the coupling between nutrient and $\mathrm{C}$ cycling, which are emerging proper- ties of GOLUM-CNP, are used to evaluate the capabilities of GOLUM-CNP to capture observed patterns among biomes. We found that there are some differences between our datadriven estimates and previous studies about the nutrient efficiencies at the biome scales (Gill and Finzi, 2016) and the openness (Cleveland et al., 2013). In this section, we discuss the major uncertainties in our model and show how these uncertainties affect the computation of nutrient efficiencies and the openness (Sect. 5.1). Of note is that most of our discussions are for the $\mathrm{C}$ cycle (based on the sensitivity analysis, see below), and since CARDAMOM is the only data-driven $\mathrm{C}$ cycle to our knowledge, the modifications of the CARDAMOM data set we made in this section are more qualitative and diagnostic rather than deterministic. Such an example highlights some important variables that should be investigated or considered in future data-driven products.

\subsection{Sensitivity to $\mathrm{C}$ variables}

Our estimates of nutrient-use efficiencies differed significantly from those estimated from in situ measurements (red squares and diamonds in Fig. 7) by Gill and Finzi (2016), particularly the values of PUE for all biomes and NUE for temperate and boreal forests. NUE and PUE were determined by NPP-allocation fractions, stoichiometric ratios, resorption coefficients, and fractions of fire in the total outgoing C flux (Eqs. 3 and E7, where NPP is canceled by the division). The CARDAMOM observation-based analysis of the C cycle is the basis of the GOLUM-CNP modeling framework, so that errors and uncertainties in CARDAMOM for the $\mathrm{C}$ cycle translate into errors and uncertainties in GOLUM-CNP. Quantitatively, the sensitivity analysis (Figs. 8, S7-S12) indicated that $F_{\mathrm{N}}$ and $F_{\mathrm{P}}$, and thus NUE and PUE, were most sensitive to the NPP-allocation fractions (especially to woody biomass) and foliar stoichiometry. We applied the sensitivity matrix (Eq. 5) to further calculate the contribution of variances from each of these input variables, in which the uncertainties in the NPP-allocation and fire fractions were obtained from CARDAMOM and the uncertainties $(1 \sigma)$ in the $\mathrm{N}: \mathrm{C}$ and $\mathrm{P}: \mathrm{C}$ stoichiometric ratios and resorption coefficients were assumed to be $40 \%$. This $40 \%$ uncertainty was larger than the uncertainty $(20 \%)$ of the $\mathrm{N}$ : C ratios used by Wang et al. (2010), so our estimate of the contribution of uncertainties from the stoichiometric ratios was relatively large. The contribution of these different sources of uncertainty to the variances of NUE and PUE is shown in Fig. 9 for temperate coniferous forests whose NUE and PUE deviated the most from the estimate by Gill and Finzi (2016). Figure 9 shows that the NPP-allocation fractions were the largest contributors to the total variances in NUE and PUE, which totaled $>80 \%$.

The NPP-allocation coefficients in CARDAMOM were only constrained indirectly by the satellite observations of LAI and tropical aboveground biomass. The uncertainty in the CARDAMOM allocation fractions was thus substantial, 

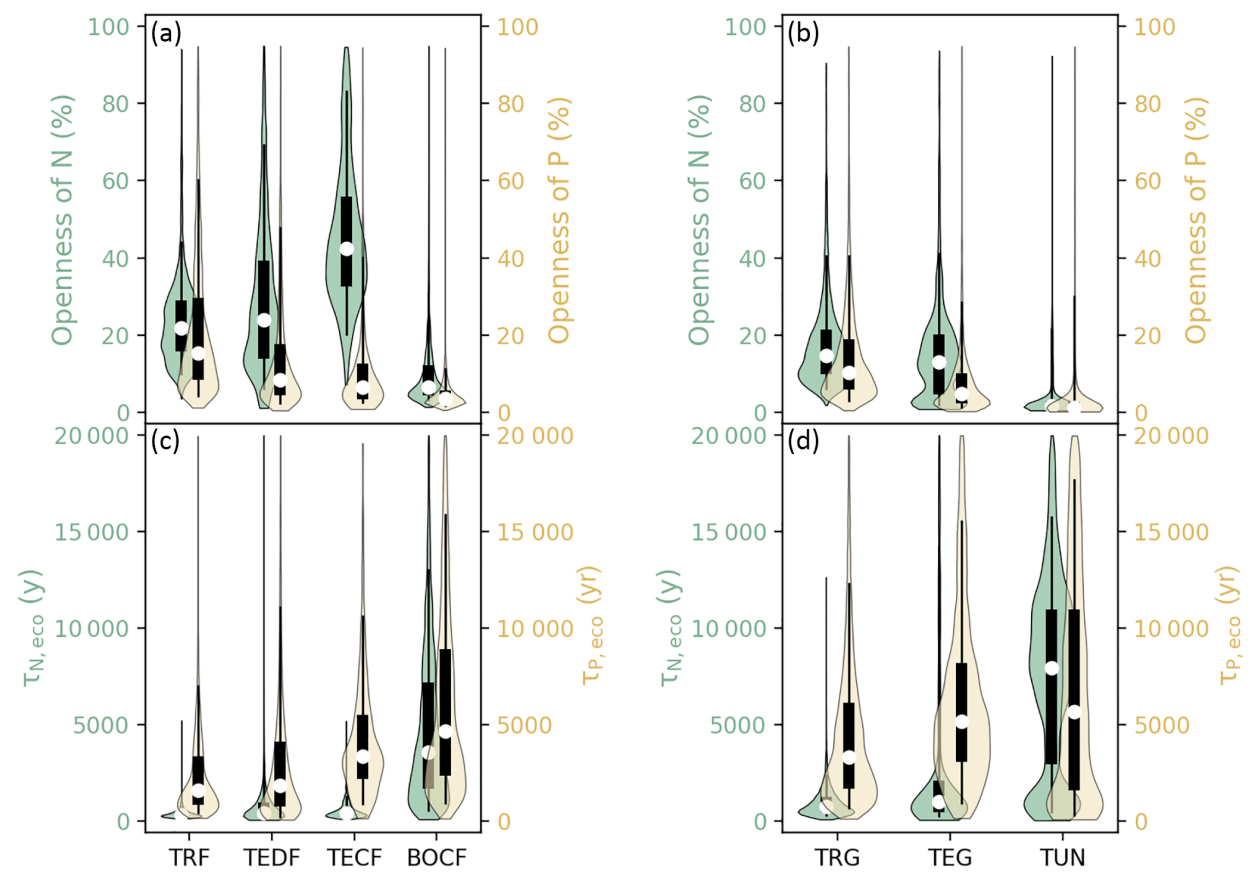

Figure 6. Violin plots of the openness of $\mathrm{N}$ and $\mathrm{P}$ cycling (the percentage of total plant uptake of $\mathrm{N}$ and $\mathrm{P}$ attributed to new nutrient inputs) for (a) forest and (b) grassland biomes. Residence times of $\mathrm{N}\left(\tau_{\mathrm{N}, \text { eco }}\right)$ and $\mathrm{P}\left(\tau_{\mathrm{P}, \text { eco }}\right)$ in (c) forest ecosystems and (d) grassland biomes. Open circles are medians of all grid cells within each biome, with balloons representing the probability density distribution of each value. Black whiskers indicate the interquartile (thick) and $95 \%$ confidence intervals (thin). The biomes are tropical rainforests (TRF), temperate deciduous forests (TEDF), temperate coniferous forests (TECF), boreal coniferous forests (BOCF), tropical/C 4 grasslands (TRG), temperate/ $\mathrm{C}_{3}$ grasslands (TEG), and tundra (TUN).

(a) Forests

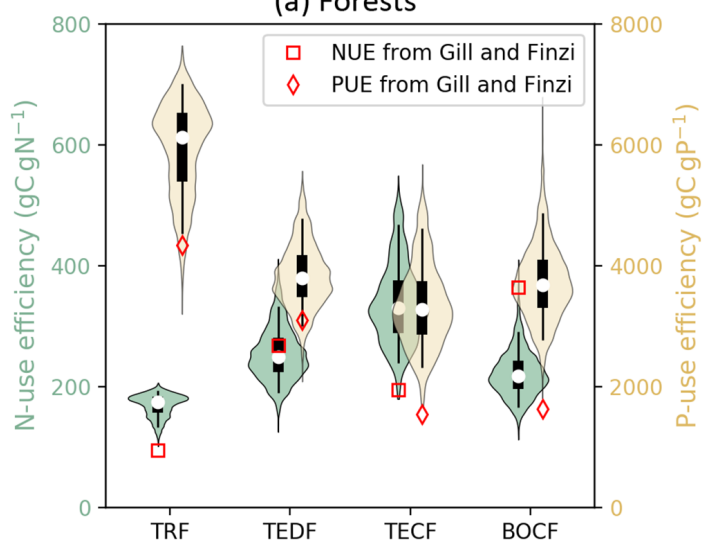

(b) Non-forest biomes

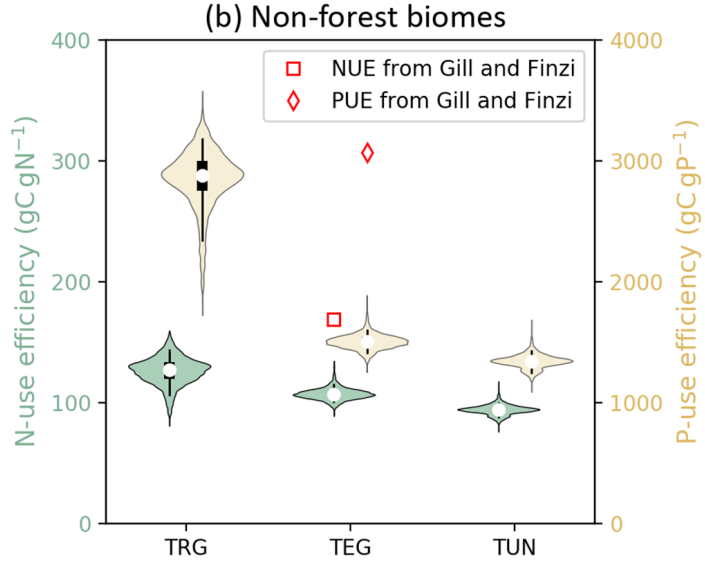

Figure 7. Violin plots of N- and P-use efficiencies (NUE and PUE, the nutrient uptake by plants divided by GPP) of seven biomes. Open circles are medians of all grid cells within each biome, with balloons representing the probability density distribution of each value. Black whiskers indicate the interquartile (thick) and $95 \%$ confidence intervals (thin). (a) Forest biomes, including tropical rainforests (TRF), temperate deciduous (TEDF), temperate coniferous (TECF), and boreal coniferous forests (BOCF). (b) Grassland biomes, including tropical/ $/ \mathrm{C}_{4}$ (TRG), temperate/ $\mathrm{C}_{3}$ grasslands (TEG), and tundra (TUN). Red squares (NUE) and diamonds (PUE) are the independent estimates from site observations and other generic data sets compiled and harmonized by Gill and Finzi (2016) based on site measurements of GPP and net N/P mineralization.

especially for non-tropical biomes where no biomass data were used (allocation-fraction 25th-75th percentile ranges are typically $>50 \%$ of the mean). For example, the mean fraction of NPP allocated to woody biomass in CAR-
DAMOM was $>60 \%$ in most grids (Fig. S13a), which is rare for field measurements (Chen et al., 2013; Doughty et al., 2015). The mean allocation of NPP to fine roots may have been underestimated, characterized by too long a turnover 

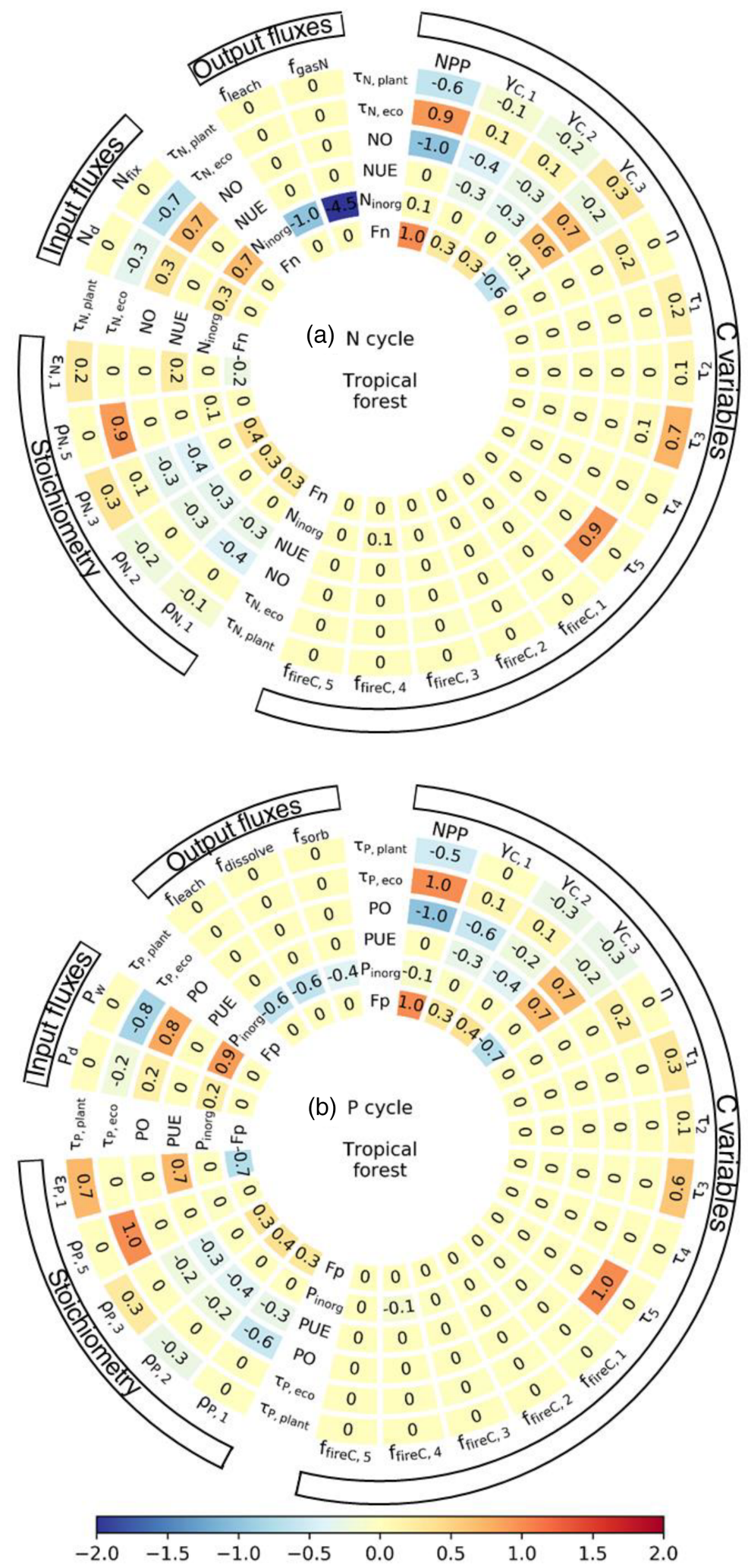

Figure 8. Mean sensitivity of the estimates of rates of nutrient uptake, inorganic nutrients, nutrient-use efficiencies, openness, turnover time of nutrients in the ecosystem, and turnover time of nutrients in plants to the input variables for tropical forest. Results for other biomes are shown in Figs. S7-S12. 


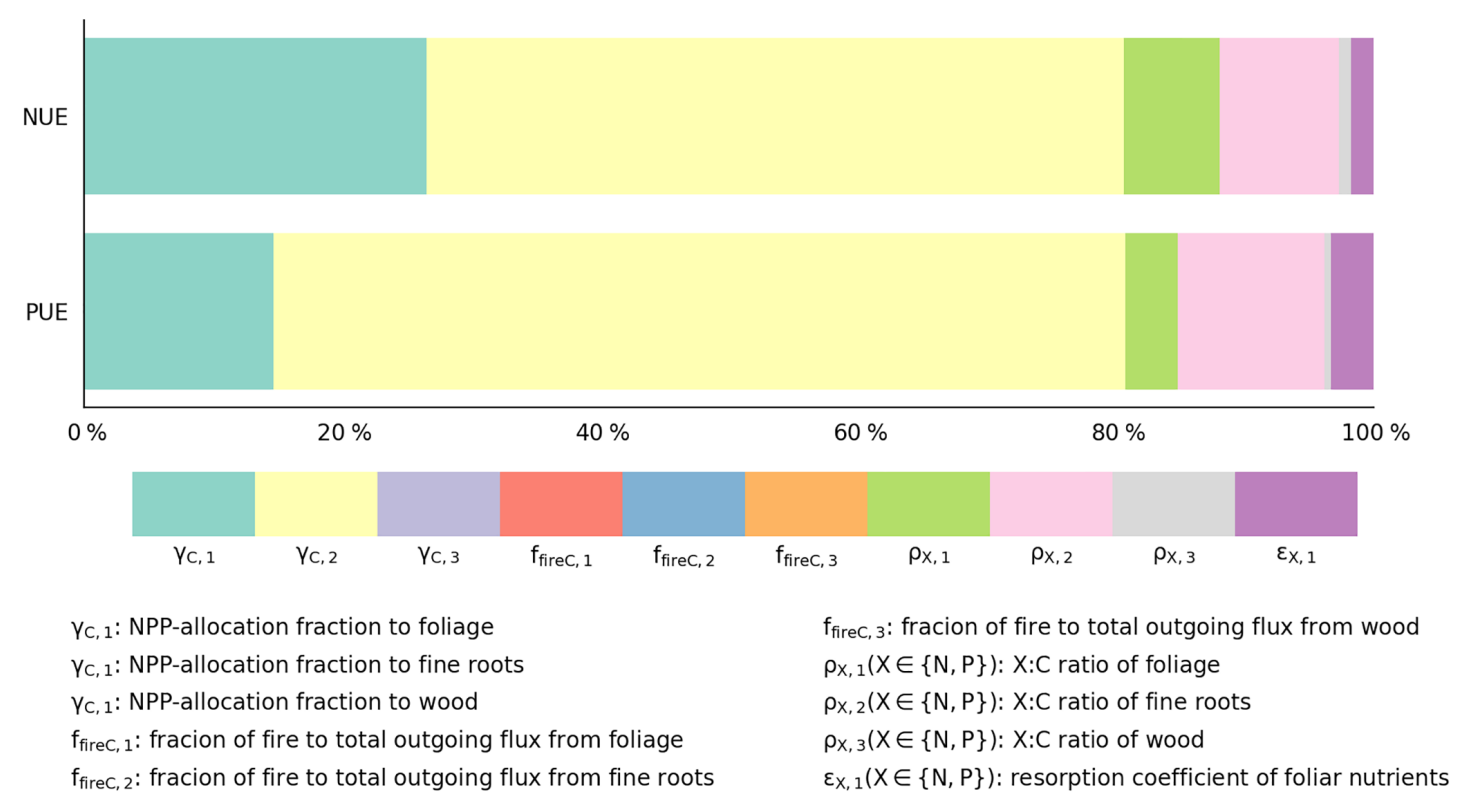

Figure 9. Contribution of input data to the variance in the estimates of nutrient-use efficiencies $(X \in\{\mathrm{N}, \mathrm{P}\})$ for temperate coniferous forests; $\gamma_{\mathrm{C}, i=1,2,3}$ are NPP-allocation fractions to foliage, fine roots, and wood, respectively. $f_{\text {fireC, } i=1,2,3}$ are fractions of fire to total outgoing flux from foliage, fine roots, and wood, respectively. $\rho_{x, i=1,2,3}(X \in\{\mathrm{N}, \mathrm{P}\})$ are $X: \mathrm{C}$ ratios of foliage, fine roots, and wood, respectively. $\varepsilon_{X, 1}$ $(X \in\{\mathrm{N}, \mathrm{P}\})$ is the resorption coefficient of foliar nutrients.

time in CARDAMOM (range from $<1$ to $10 \mathrm{yr}$ ) compared to field measurements $(<3 \mathrm{yr}$ for all ecosystems; Gill and Jackson, 2000; Green et al., 2005). The CARDAMOM results indicated a turnover time of leaves in temperate and boreal biomes of $<1 \mathrm{yr}$, while Reich et al. (2014) indicated that the typical life span of conifer needles in evergreen coniferous forests depended on temperature and ranged from 2.5 to $>10 \mathrm{yr}$, this inconsistency being attributed by Bloom et al. (2016) to the potential roles of seasonal MODIS LAI biases and to the presence of understory vegetation across highlatitude ecosystems (Heiskanen et al., 2012).

Considering these inconsistencies between mean CARDAMOM values and in situ measurements, we conducted an additional experiment in which the CARDAMOM fields were further adapted: (1) the mean NPP-allocation fractions to both woody biomass and the turnover time of woody biomass were divided by 1.5 to make sure that the NPPallocation fractions to woody biomass fall in the range of field measurements, (2) the foliage turnover time of TECF and BOCF forests, and associated NPP-allocation fractions, was adjusted (keeping foliar biomass unchanged) to match in situ observations (Reich et al., 2014) based on the fitted relationship between the needle longevity and mean annual temperature from Reich et al. (2014), assuming that understory vegetation plays a minimal role in $\mathrm{C}, \mathrm{N}$, and $\mathrm{P}$ cycling, and (3) in CARDAMOM, the NPP was constrained by GPP (GPP being constrained by the observation of LAI and the relationship between LAI and GPP) and the observation of biomass, additional adjustments were made to conserve the total NPP and pool sizes estimated from CARDAMOM by allocating the residual NPP after the modifications from step 1 and 2 to fine roots, and adjusting the turnover time of fine roots to exactly conserve the pool size of CARDAMOM (see Figs. S13-S16 for the adjusted variables and original CARDAMOM values). Fig. 10 shows the NUE and PUE from this new experiment based on this modified version of the $\mathrm{C}$ cycle from CARDAMOM. The NUE and PUE were lower than those in Fig. 7 for the forest biomes, especially for TECF and BOCF, which tended to decrease PUE from tropical to boreal forest. This distribution of PUE among the biomes in Fig. 10 better matched the differences between biomes presented by Gill and Finzi (2016). Remaining inconsistencies could be attributed to the different methods used in this study and by Gill and Finzi (2016) are different. For example, Gill and Finzi (2016) notably used the net mineralization rates of $\mathrm{N}$ and $\mathrm{P}$ to approximate plant uptake, because their differences were 1 order of magnitude smaller than net nutrient mineralization. These authors used in situ measurements of net $\mathrm{N}$ mineralization but used a statistical model to estimate $\mathrm{P}$ mineralization based on a soil-order-specific soil-P pool due to the lack of data (Yang and Post, 2011) and a regression between soil-P turnover times and mean annual temperature. Their estimate of plant uptake was thus independent of vegetation stoichiometry, which differed from our study. Gill and Finzi (2016) also used bootstrapping to sample the NPP and net $\mathrm{N}$ (or P) mineralization from independent studies. Their estimates of NUE and PUE were thus not based on paired data, so their estimates may contain some sampling errors. 

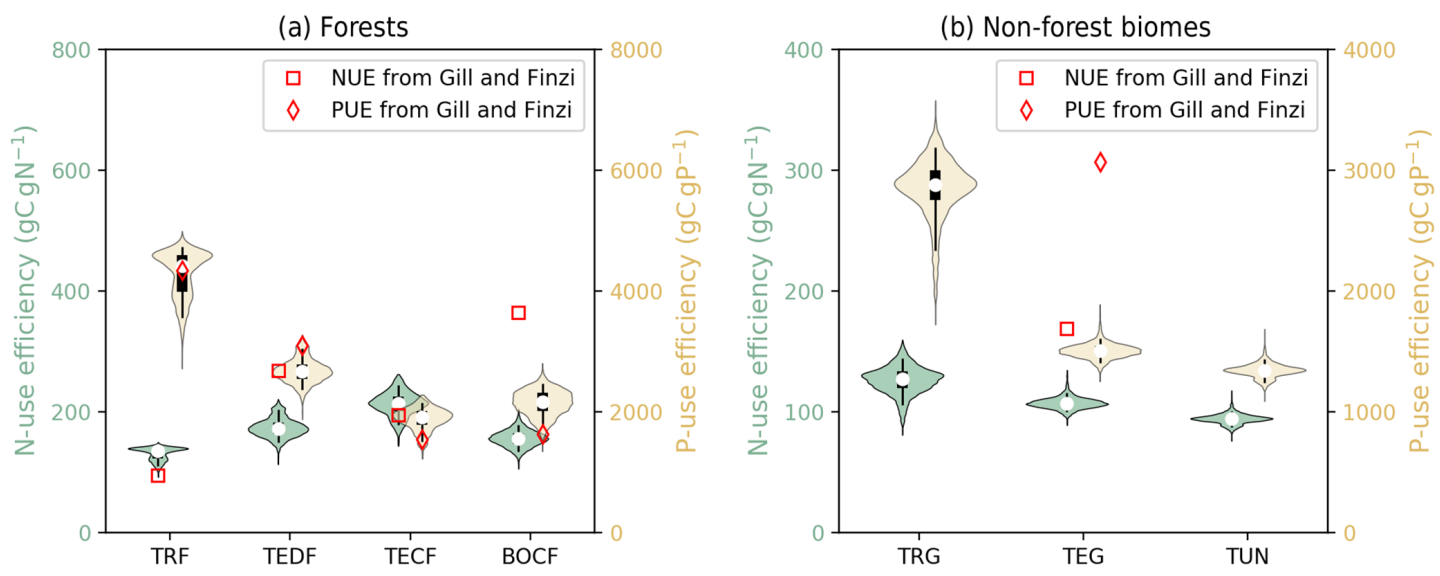

Figure 10. Violin plots of the nutrient-use efficiencies of the seven biomes from the experiment in which the allocation fraction of NPP to woody biomass and to leaves in coniferous forests is reduced. Open circles are the medians of all grid cells within each biome, with balloons representing the probability density distribution of each value. Black whiskers indicate interquartile (thick) and $95 \%$ confidence intervals (thin). The biomes are tropical rainforests (TRF), temperate deciduous forests (TEDF), temperate coniferous forests (TECF), boreal coniferous forests (BOCF), tropical/C 4 grasslands (TRG), temperate/ $\mathrm{C}_{3}$ grasslands (TEG), and tundra (TUN). The red squares (NUE) and diamonds (PUE) are the independent estimates from site observations and other generic data sets compiled and harmonized by Gill and Finzi (2016) based on site measurements of GPP and net N/P mineralization.

\subsection{Uncertainty in nutrient-cycle openness}

The distribution of nutrient-cycle openness in the seven biomes are presented in Sect. 4.3 and Fig. 6. Our estimate of a small openness of $\mathrm{N}$ and $\mathrm{P}$ in BOCF, and that the openness was smaller for the $\mathrm{P}$ than the $\mathrm{N}$ cycle, is consistent with the estimates by Cleveland et al. (2013). Our estimates of the $\mathrm{N}$ openness, however, are about twice as large as the estimates of Cleveland et al. (2013). This difference is due to the larger deposition fluxes in our study (globally $72 \mathrm{Tg} \mathrm{N} \mathrm{yr}^{-1}$ ) than those used by Cleveland et al. (2013; $33 \mathrm{Tg} \mathrm{Nyr}^{-1}$; from Dentener, 2006), because Wang et al. (2017) used an atmospheric model with higher horizontal resolution and an updated inventory of reactive- $\mathrm{N}$ (e.g., $\mathrm{NO}_{x}$ and $\mathrm{NH}_{3}$ ) emission (Wang et al., 2017) and also because Cleveland et al. (2013) assumed that only $15 \%$ of deposited $\mathrm{N}$ was available to plants. Cleveland et al. (2013) demonstrated that changing the fraction of biologically available deposited $\mathrm{N}$ to $100 \%$ did not significantly change the openness, because $\mathrm{N}$-deposition fluxes were generally smaller than $\mathrm{N}$ fixation and accounted for a small fraction of external $\mathrm{N}$ inputs in their study. Our estimates of $\mathrm{P}$ openness are also larger than those of Cleveland et al. (2013), which we attributed to the large differences in the estimates of $\mathrm{P}$ deposition between the two studies. Cleveland et al. (2013) used P deposition $\left(0.26 \mathrm{Tg} \mathrm{yr}^{-1}\right)$ from Mahowald et al. (2008), which were 1 order of magnitude lower than recent estimates from Wang et al. (2017) used in this study $\left(5.8 \mathrm{Tg} \mathrm{yr}^{-1}\right)$, because Wang et al. (2017) revised the contribution of anthropogenic P emissions and $\mathrm{P}$ in particles with diameters $>10 \mu \mathrm{m}$ (Wang et al., 2015, 2017). We also found that the P-cycle openness decreased from the tropics to the boreal region, in contrast to the results by Cleveland et al. (2013). This also derives from the differences in the spatial gradients of $\mathrm{P}$ deposition in the two studies. Mahowald et al. (2008) found that P deposition was largest in northern Africa and that $\mathrm{P}$ deposition was within the same order of magnitude for tropical and temperate forests. Wang et al. (2017), however, found that P deposition was much larger over tropical forests than other regions. The contrasting spatial gradients in P deposition was likely due to the different models of atmospheric transport used by Wang et al. (2017) and Mahowald et al. (2008). More importantly, most stations measuring total $\mathrm{P}$ deposition are in temperate regions, and measurements of $\mathrm{P}$ deposition over tropical forests are very limited (Mahowald et al., 2008; Wang et al., 2017), so the estimates of $\mathrm{P}$ deposition in the tropics were not well constrained by in situ observations and thus had large uncertainties. Differences in the spatial gradients in nutrient-cycle openness between our study and the study by Cleveland et al. (2013) demonstrated the impact of uncertain input data sets on the estimate of ecologically relevant quantities. The quantitative assessment of the uncertainties in our estimates of openness, however, was difficult, because the potential uncertainties in these data sets were not systematically evaluated within and between different estimates, and should therefore be addressed in future studies.

\subsection{Future research and data needs}

Our estimates of global $\mathrm{N}$ and $\mathrm{P}$ cycles were at the scale of large biomes. Recent studies of $\mathrm{N}$ and $\mathrm{P}$ cycles have relied on biome-specific stoichiometry (Cleveland et al., 2013; Wang et al., 2010). Stoichiometry, however, is also highly variable within biomes (Reich and Oleksyn, 2004). For ex- 
ample, Kattge et al. (2011) found that $40 \%$ of the variability in foliar $\mathrm{N}$ content was within species (finer scale than that of large biomes) and suggested that these stoichiometric ratios may be better represented by future trait-based estimates rather than fixed species-specific values. Some improvements have been made on the variation of stoichiometric ratios across climatic and ecological gradients within and across biomes, and on the contribution of plant traits and environmental conditions to these variations (Dong et al., 2017; Han et al., 2005; Meyerholt and Zaehle, 2015). However, it is still not sufficient to derive a globally gridded overview of the $\mathrm{N}$ and $\mathrm{P}$ cycles on current knowledge. A better understanding of the stoichiometric variability, and its drivers, is still needed in terms of not only representing the largescale gradients but also reducing the uncertainties at the local scale. New and spatially interpolated stoichiometric data sets should partly overcome this problem, although uncertainties in the interpolation will need to be carefully propagated on GOLUM-CNP outputs.

We assumed that all terrestrial ecosystems were at a steady state for 2001-2010 due to a lack of global constraints on the dynamics of $\mathrm{N}$ and $\mathrm{P}$ cycling over a long period. Terrestrial ecosystems, however, are not currently at steady states (Luo and Weng, 2011), due to climate change, increasing atmospheric $\mathrm{CO}_{2}$, anthropogenic disturbance etc, (Friedlingstein et al., 2006; Sitch et al., 2015). Zaehle (2013) reported that the terrestrial biosphere has accumulated $1.2 \mathrm{Pg} \mathrm{N}$ and 134.0 Pg C since the pre-industrial period. Wang et al. (2017) also found that $\mathrm{N}$ and $\mathrm{P}$ deposition have changed dramatically over time. The simulations by different models vary considerably, e.g., the responses of the biosphere to the increasing atmospheric $\mathrm{CO}_{2}$ (Zaehle et al., 2014) and thus in future projections, because the current data sets have had little success in constraining all key processes in most DGVMs. Our results contribute to evaluating models simulating global biogeochemical cycles. Although our steady-state C pool sizes (given the NPP and residence time at the condition of current climate) were within the $[25,75 \mathrm{th}]$ percentile range of the original non-steady-state CARDAMOM results (Fig. S1) at most grid cells, the biomass C stocks at 5\%-10\% of forest grid cells exceed the uncertainty range of CARDAMOM. In addition, independent remote-sensing estimates for 30 to $80^{\circ} \mathrm{N}$ were $4.76 \pm 1.78 \mathrm{~kg} \mathrm{C} \mathrm{m}^{-2}$ for mean forest $\mathrm{C}$ density and $79.8 \pm 29.9 \mathrm{PgC}$ for total forest $\mathrm{C}$ (Thurner et al., 2014), which were lower than the GOLUM-CNP estimates $\left(6.51 \mathrm{~kg} \mathrm{C} \mathrm{m}^{-2}\right.$ for mean forest $\mathrm{C}$ density across pixels defined as forest in Fig. 2, and $181 \mathrm{PgC}$ for total forest C) for this region. This inconsistency was largely due to the fact that northern temperate and boreal forests may deviate substantially from their equilibrium for the current NPP (Pan et al., 2011), because of climate change and elevated $\mathrm{CO}_{2}$. Residual overestimation could also be due to the fact that biomass removal by harvesting and from disturbance other than fires was not explicitly constrained in CARDAMOM and thus not represented in GOLUM-CNP. A transient sim- ulation of $\mathrm{N}$ and $\mathrm{P}$ cycling will be needed in future studies as more constraints on $\mathrm{N}$ and $\mathrm{P}$ cycles emerge to study the effects of climate change, increasing $\mathrm{CO}_{2}$ levels and disturbance on $\mathrm{N}$ and $\mathrm{P}$ cycles and their feedbacks. In such a transient simulation, a key process would be to simulate both the short-term and long-term responses of plants to the changing environment, e.g., how the plants would react when the inorganic $\mathrm{N}$ or labile soil $\mathrm{P}$ was not sufficient. Different models assumed different hypotheses under these conditions. For instance, $\mathrm{N}: \mathrm{C}$ and $\mathrm{P}: \mathrm{C}$ ratios are fixed and the photosynthesis rate is reduced to meet the low uptake of nutrients in Thornton et al. (2007). In Wang et al. (2010), the $\mathrm{N}: \mathrm{C}$ and $\mathrm{P}: \mathrm{C}$ ratios in biomass can vary within certain ranges, insufficient nutrient uptake would first result in a low concentration of $\mathrm{N}$ and/or $\mathrm{P}$ in plant tissues and the low concentration of nutrients would then limit photosynthesis according to an empirical relationship between nutrient concentration and NPP. Similarly, when the $\mathrm{N}: \mathrm{C}$ and $\mathrm{P}: \mathrm{C}$ ratios in litter change, the decomposition rate of litter would change as a result of the altered activity of microbes (Manzoni et al., 2017). In the future, more data are required to test these hypotheses and the transient simulation of the next version of GOLUM-CNP should incorporate these interactions between the plants and environments.

In addition, some processes, such as the $\mathrm{N}$ inputs from rock weathering (Houlton et al., 2018), were not considered in this study, because (1) as stated in Houlton et al. (2018), it is still unknown how much of rock-released $\mathrm{N}$ can be used by plants when rock weathering happens deep beneath the soils; (2) in GOLUM-CNP, adding rock $\mathrm{N}$ inputs has the same effect as $\mathrm{N}$ fixation and $\mathrm{N}$ deposition (Eqs. B6 and E17); and (3) the estimate of total input of $\mathrm{N}$ to ecosystems $\left(188 \mathrm{Tg} \mathrm{N} \mathrm{yr}^{-1}\right)$ in this study are already at the higher end of the estimate (mean $147 \mathrm{Tg} \mathrm{yr}^{-1}$, and range between 99.1 and $185.1 \mathrm{Tg} \mathrm{yr}^{-1}$ ) of Houlton et al. (2018), even if rock $\mathrm{N}$ inputs are not accounted for, due to our larger estimates of $\mathrm{N}$ fixation and $\mathrm{N}$ deposition than Houlton et al. (2018). In the future, the rock $\mathrm{N}$ inputs and the fraction of these $\mathrm{N}$ inputs accessible to plants should be further quantified and the quantity of total $\mathrm{N}$ inputs to the ecosystems should be reconciled between different studies. And the future development of data-driven GOLUM-CNP should be in-line with the latest understanding of $\mathrm{C}, \mathrm{N}$, and $\mathrm{P}$ cycles.

The model structure of GOLUM-CNP is mainly described by the inputs (NPP for $\mathrm{C}$ cycle, $\mathrm{N}$ deposition and fixation for $\mathrm{N}$ cycle, and $\mathrm{P}$ deposition and release from rock weathering for P cycle) and residence times. Most DGVMs (e.g., Goll et al., 2012, 2017a; Medvigy et al., 2009; Parton et al., 2010; Thornton et al., 2007; Wang et al., 2010; Weng and Luo, 2008; Xu-Ri and Prentice, 2008; Yang et al., 2009; Zaehle et al., 2014; Zaehle and Friend, 2010) can be summarized by these two components, although these models have more processes and use complex equations to describe the dynamics controlling carbon and nutrient distribution among pools and the turnover of each pool. In this context, the output of the 
GOLUM-CNP provides a traceable tool that can be used in the future to compare the results between GOLUM-CNP and different DGVMs. As DGVMs are capable of computing the steady state of the biogeochemical cycles for present conditions, a direct comparison between GOLUM-CNP estimates and DGVMs' estimates is possible.

At last, the sensitivity matrix presented in Sect. 4.4 provides a useful tool for assessing the uncertainties in model outputs by propagating the uncertainties in the model inputs. We applied this method to quantitatively assess the sources of uncertainties in the estimated nutrient-use efficiencies (Sect. 5.1 and Fig. 9), but we also found that the uncertainties for some other quantities were currently difficult to obtain, because the estimates of uncertainties were not available for all spatially explicit input data. This sensitivity analysis can be used in future studies to quantify the contribution of each input data set to the uncertainty in other model outputs, to characterize the dominant sources of uncertainties in the estimated $\mathrm{C}, \mathrm{N}$, and $\mathrm{P}$ processes, to identify the major differences between different models (e.g., GOLUMCNP versus DGVMs), and thus to identify priorities for future data syntheses to fill the largest gaps in uncertainty. Future studies that provide global data sets will need to include systematic evaluations and spatially explicit estimates of uncertainties in their data sets.

\section{Concluding remarks}

This study is a first attempt to combine observation-based estimates of $\mathrm{C}, \mathrm{N}$, and $\mathrm{P}$ fluxes and pools in terrestrial ecosystems into a consistent (steady-state) diagnostic model. Although there are considerable uncertainties in our results due to uncertain and incomplete carbon cycle and nutrient observations, the main findings are the following: (1) external inputs of $\mathrm{P}$ from outside the ecosystem contributes to a smaller plant $\mathrm{P}$ uptake than that of $\mathrm{N}$, indicating a more important role of internal $\mathrm{P}$ recycling than that of internal $\mathrm{N}$ recycling in supporting plant growth and (2) tropical forests have the lowest $\mathrm{N}$ use efficiency and the largest $\mathrm{P}$ use efficiency, suggesting the adaptive response of this biome to the low P availability in the tropics. The structure of GOLUMCNP is analogous to most other process-based DGVMs describing carbon and nutrient interactions. The output of the GOLUM-CNP provides a traceable tool and can be used in the future to test the performance of complex DGVMs in the simulation of interactions between $\mathrm{C}, \mathrm{N}$, and $\mathrm{P}$ cycling.
Code and data availability. The source code and the map of the classification of the seven large biomes are included in the Supplement. For the other data sets that are listed in Table 1, it is encouraged to contact the first authors of the original references. 


\section{Appendix A: Equations for carbon cycle}

The carbon cycle framework is based on the DALEC2 model (Bloom and Williams, 2015), except that we combined the labile and foliage pools together since the labile pool in DALEC2 only transfer to foliage. There are five pools in the C cycle (1: foliage; 2: fine roots; 3: wood; 4: litter; 5: SOM). The equations governing the change of $\mathrm{C}$ pools are given by

$\frac{\mathrm{d} C_{1}}{\mathrm{~d} t}=-\tau_{1}^{-1} C_{1}+\gamma_{1} \mathrm{Fc}$,

$\frac{\mathrm{d} C_{2}}{\mathrm{~d} t}=-\tau_{2}^{-1} C_{2}+\gamma_{2} \mathrm{Fc}$,

$\frac{\mathrm{d} C_{3}}{\mathrm{~d} t}=-\tau_{3}^{-1} C_{3}+\gamma_{3} \mathrm{Fc}$,

$\frac{\mathrm{d} C_{4}}{\mathrm{~d} t}=\tau_{1}^{-1} C_{1}\left(1-f_{\text {fireC }, 1}\right)+\tau_{2}^{-1} C_{2}\left(1-f_{\text {fireC }, 2}\right)$

$$
-\tau_{4}^{-1} C_{4} \text {, }
$$

$\frac{\mathrm{d} C_{5}}{\mathrm{~d} t}=\tau_{3}^{-1} C_{3}\left(1-f_{\text {fireC }, 3}\right)+\eta \tau_{4}^{-1} C_{4}-\tau_{5}^{-1} C_{5}$.

The definitions of the symbols are listed in Table 1.

\section{Appendix B: Equations for nitrogen cycle}

There are five organic $\mathrm{N}$ pools and one inorganic soil $\mathrm{N}$ pool. The $\mathrm{N}$ cycle is described by the following equations:

$$
\begin{aligned}
& \frac{\mathrm{d} N_{1}}{\mathrm{~d} t}=-\tau_{1}^{-1} N_{1}\left(1-\varepsilon_{1}\right)+\beta_{1} \mathrm{Fn} \\
& \frac{\mathrm{d} N_{2}}{\mathrm{~d} t}=-\tau_{2}^{-1} N_{2}+\beta_{2} \mathrm{Fn} \\
& \frac{\mathrm{d} N_{3}}{\mathrm{~d} t}=-\tau_{3}^{-1} N_{3}+\beta_{3} \mathrm{Fn} \\
& \frac{\mathrm{d} N_{4}}{\mathrm{~d} t}=\tau_{1}^{-1} N_{1}\left(1-\varepsilon_{1}\right)\left(1-f_{\text {fireC }, 1}\right) \\
& \quad+\tau_{2}^{-1} N_{2}\left(1-f_{\text {fireC }, 2}\right)-\tau_{4}^{-1} N_{4} \\
& \frac{\mathrm{d} N_{5}}{\mathrm{~d} t}=\tau_{3}^{-1} N_{3}\left(1-f_{\text {fireC }, 3}\right)+\eta \tau_{4}^{-1} N_{4} \\
& \quad+N_{\text {imob }}-\tau_{5}^{-1} N_{5}, \\
& \frac{\mathrm{d} N_{\text {inorg }}}{\mathrm{d} t}=\tau_{5}^{-1} N_{5}\left(1-f_{\text {fireC }, 5}\right)+\tau_{4}^{-1} N_{4}\left(1-\eta-f_{\text {fireC }, 4}\right) \\
& \quad+N_{\mathrm{d}}+N_{\text {fix }}-N_{\text {imob }}-f_{\text {leach }} N_{\text {inorg }} \\
& \quad-f_{\text {denit }} N_{\text {inorg }}-\text { Fn. }
\end{aligned}
$$

The definitions of the symbols are listed in Table 1.

In Eq. (B6), the fraction of inorganic $\mathrm{N}$ ( $\left.f_{\text {leach }}\right)$ that is lost due to leaching is computed by soil water $(\Theta)$ and the sum of drainage and surface runoff $(q)$. We use the spatially explicit estimate of daily soil moisture derived from the European Centre for Medium-Range Weather Forecasts (ECMWF) Interim Reanalysis (ERA-Interim/Land; Albergel et al., 2013; Balsamo et al., 2015; see Table 1), and the global gridded estimate of monthly mean runoff data from the Global Runoff
Data Centre (GRDC, http://www.grdc.sr.unh.edu/, last access: 8 May 2017). Since the runoff data only have a monthly time step, we use the same value of runoff for each day within 1 month. The leaching fraction at the annual timescale is thus computed by

$f_{\text {leach }}=\sum_{d=1}^{365} \frac{q_{i}}{\Theta_{i}+q_{i}}$.

Of note is that in this computation $f_{\text {leach }}$ can exceed 1 , meaning that the turnover time of inorganic $\mathrm{N}$ pool is smaller than 1 year (Wang et al., 2010).

\section{Appendix C: Equations for phosphorus cycle}

There are five organic P pools and one inorganic soil P pool. The $\mathrm{P}$ cycle are described by the following equations:

$$
\begin{aligned}
& \frac{\mathrm{d} P_{1}}{\mathrm{~d} t}=-\tau_{1}^{-1} P_{1}\left(1-\theta_{1}\right)+\varphi_{1} \mathrm{Fp} \\
& \frac{\mathrm{d} P_{2}}{\mathrm{~d} t}=-\tau_{2}^{-1} P_{2}+\varphi_{2} \mathrm{Fp} \\
& \frac{\mathrm{d} P_{3}}{\mathrm{~d} t}=-\tau_{3}^{-1} P_{3}+\varphi_{3} \mathrm{Fp} \\
& \frac{\mathrm{d} P_{4}}{\mathrm{~d} t}=\tau_{1}^{-1} P_{1}\left(1-\theta_{1}\right)\left(1-f_{\text {fireC }, 1}\right)+\tau_{2}^{-1} P_{2}\left(1-f_{\text {fireC }, 2}\right) \\
& \quad-\tau_{4}^{-1} P_{4}, \\
& \frac{\mathrm{d} P_{5}}{\mathrm{~d} t}=\tau_{3}^{-1} P_{3}\left(1-f_{\text {fireC }, 3}\right)+\eta \tau_{4}^{-1} P_{4} \\
& \quad+P_{\text {imob }}-\tau_{5}^{-1} P_{5}, \\
& \frac{\mathrm{d} P_{\text {inorg }}}{\mathrm{d} t}=\tau_{5}^{-1} P_{5}\left(1-f_{\text {fireC }, 5}\right)++\tau_{4}^{-1} P_{4}\left(1-\eta-f_{\text {fireC }, 4}\right) \\
& \quad+P_{\mathrm{d}}+P_{\mathrm{w}}+0.75 \text { Fire } \mathrm{P}-P_{\text {imob }}-f_{\text {leach }} f_{\text {dissolve }} P_{\text {inorg }} \\
& \quad-f_{\text {sorb }} P_{\text {inorg }}+\text { Fp. }
\end{aligned}
$$

Where Firep represents the $\mathrm{P}$ in the ecosystem that suffers from fire events:

$$
\begin{aligned}
& \text { Fire }_{\mathrm{P}}=\tau_{1}^{-1} P_{1}\left(1-\theta_{1}\right) f_{\text {fireC }, 1}+\tau_{2}^{-1} P_{2} f_{\text {fireC }, 2} \\
& \quad+\tau_{3}^{-1} P_{3} f_{\text {fireC }, 3}+\tau_{4}^{-1} P_{4} f_{\text {fireC }, 4}+\tau_{5}^{-1} P_{5} f_{\text {fireC }, 5}
\end{aligned}
$$

\section{Appendix D: Additional constraints}

1. Under a steady state, the $\mathrm{N}: \mathrm{C}$ and $\mathrm{P}: \mathrm{C}$ ratios for the plants and soil are assumed to be constant, so that $N_{i}$ and $P_{i}$ can be calculated by the production of the $\mathrm{C}$ pool size from CARDAMOM and the stoichiometry ratios for each pool from Zechmeister-Boltenstern et al. (2015), except litter which has different definitions in CARDAMOM and Zechmeister-Boltenstern et al. (2015):

$$
\begin{aligned}
& N_{i}=\rho_{\mathrm{N}, i} C_{i}(i=1,2,3,5), \\
& P_{i}=\rho_{\mathrm{P}, i} C_{i}(i=1,2,3,5) .
\end{aligned}
$$


2. The fraction of NPP, $F_{\mathrm{N}}$, and $F_{\mathrm{P}}$ allocations sum up to 1 :

$$
\begin{aligned}
& \beta_{1}+\beta_{2}+\beta_{3}=1, \\
& \varphi_{1}+\varphi_{2}+\varphi_{3}=1 .
\end{aligned}
$$

3. The fraction of gaseous loss of $\mathrm{N}$ due to denitrification to the total inorganic $\mathrm{N}$ loss should satisfy the estimates by using global $\delta^{15} \mathrm{~N}$ observations $\left(f_{\text {gas }}\right.$, Goll et al., 2017b):

$$
\frac{f_{\text {denit }} N_{\text {inorg }}}{f_{\text {leach }} N_{\text {inorg }}+f_{\text {denit }} N_{\text {inorg }}}=f_{\text {gasN }} .
$$

\section{Appendix E: Solutions under steady-state assumption}

$C_{i}=F_{\mathrm{c}} \gamma_{\mathrm{C}, i} \tau_{i}(i=1,2,3)$,

$C_{4}=\left[\frac{C_{1}}{\tau_{1}}\left(1-f_{\text {fireC }, 1}\right)+\frac{C_{2}}{\tau_{2}}\left(1-f_{\text {fireC }, 2}\right)\right] \tau_{4}$,

$C_{5}=\left[\frac{C_{3}}{\tau_{3}}\left(1-f_{\text {fireC }, 3}\right)+\frac{C_{4}}{\tau_{4}}\left(1-f_{\text {fire }, 4}\right)\right] \tau_{5}$,

$F_{\mathrm{N}}=F_{\mathrm{c}}\left[\rho_{\mathrm{N}, 1} \gamma_{\mathrm{C}, 1}\left(1-f_{\text {fireC }, 1}\right)\left(1-\varepsilon_{\mathrm{N}, 1}\right)\right.$

$\left.+\rho_{\mathrm{N}, 1} \gamma_{\mathrm{C}, 1} f_{\text {fireC }, 1}+\rho_{\mathrm{N}, 2} \gamma_{\mathrm{C}, 2}+\rho_{\mathrm{N}, 2} \gamma_{\mathrm{C}, 3}\right]$,

$\gamma_{\mathrm{N}, 2}=\frac{\rho_{\mathrm{N}, 2} C_{2}}{\tau_{2} F_{\mathrm{N}}}$,

$\gamma_{\mathrm{N}, 3}=\frac{\rho_{\mathrm{N}, 3} C_{3}}{\tau_{3} F_{\mathrm{N}}}$,

$\gamma_{\mathrm{N}, 1}=1-\gamma_{\mathrm{N}, 2}-\gamma_{\mathrm{N}, 3}$,

$N_{i}=\rho_{\mathrm{N}, \mathrm{i}} C_{i}(i=1,2,3,5)$,

$N_{4}=\frac{\frac{\rho_{\mathrm{N}, 1} C_{1}}{\tau_{1}}\left(1-f_{\text {fireC }, 1}\right)+\frac{\rho_{\mathrm{N}, 2} C_{2}}{\tau_{2}}\left(1-f_{\text {fireC }, 2}\right)}{\frac{C_{1}}{\tau_{1}}\left(1-f_{\text {fireC }, 1}\right)+\frac{C_{2}}{\tau_{2}}\left(1-f_{\text {fireC }, 2}\right)} C_{4}$,

$N_{\text {imorb }}=\eta\left(\rho_{\mathrm{N}, 5}-\frac{N_{4}}{C_{4}}\right) \frac{C_{4}}{\tau_{4}}+\left(\rho_{\mathrm{N}, 5}-\frac{N_{3}}{C_{3}}\right)$

$$
\frac{C_{3}}{\tau_{3}}\left(1-f_{\text {fireC }, 3}\right),
$$

$N_{\text {inorg }}=\frac{N_{\mathrm{d}}+N_{\text {fix }}-\sum_{i=1}^{5}\left(\frac{N_{i}}{\tau_{i}} f_{\text {fireC }, i}\right)}{f_{\text {leach }}}$,

$F_{\mathrm{P}}=F_{\mathrm{c}}\left[\rho_{\mathrm{P}, 1} \gamma_{\mathrm{C}, 1}\left(1-f_{\text {fireC }, 1}\right)\left(1-\varepsilon_{\mathrm{P}, 1}\right)+\rho_{\mathrm{P}, 1} \gamma_{\mathrm{C}, 1} f_{\text {fireC }, 1}\right.$

$$
\left.+\rho_{\mathrm{P}, 2} \gamma_{\mathrm{C}, 2}+\rho_{\mathrm{P}, 2} \gamma_{\mathrm{C}, 3}\right] \text {, }
$$

$\gamma_{\mathrm{P}, 2}=\frac{\rho_{\mathrm{P}, 2} C_{2}}{\tau_{2} F_{\mathrm{P}}}$,

$\gamma_{\mathrm{P}, 3}=\frac{\rho_{\mathrm{P}, 3} C_{3}}{\tau_{3} F_{\mathrm{P}}}$,

$\gamma_{\mathrm{P}, 1}=1-\gamma_{\mathrm{P}, 2}-\gamma_{\mathrm{P}, 3}$

$P_{i}=\rho_{\mathrm{P}, i} C_{i}(i=1,2,3,5)$,

$P_{4}=\frac{\frac{\rho_{\mathrm{P}, 1} C_{1}}{\tau_{1}}\left(1-f_{\text {fireC }, 1}\right)+\frac{\rho_{\mathrm{P}, 2} C_{2}}{\tau_{2}}\left(1-f_{\text {fireC }, 2}\right)}{\frac{C_{1}}{\tau_{1}}\left(1-f_{\text {fireC }, 1}\right)+\frac{C_{2}}{\tau_{2}}\left(1-f_{\text {fireC }, 2}\right)} C_{4}$,
$P_{\text {imorb }}=\eta\left(\rho_{\mathrm{P}, 5}-\frac{P_{4}}{C_{4}}\right) \frac{C_{4}}{\tau_{4}}+\left(\rho_{\mathrm{P}, 5}-\frac{P_{3}}{C_{3}}\right)$

$\frac{C_{3}}{\tau_{3}}\left(1-f_{\text {fireC }, 3}\right)$,

$P_{\text {inorg }}=\frac{P_{\mathrm{d}}+P_{\mathrm{w}}-\sum_{i=1}^{5}\left(\frac{P_{i}}{\tau_{i}} f_{\text {fireC }, i}\right)}{f_{\text {leach }} f_{\text {dissolve }}+f_{\text {sorb }}}$. 
Supplement. The supplement related to this article is available online at: https://doi.org/10.5194/gmd-11-3903-2018-supplement.

Author contributions. PC, YL, and YPW designed the research; DG, YPW, AAB, JH, RW, and SZ provided the datasets; YW, DG, YH, BDS, and SZ analyzed the data; and YW, PC, DG, YH, YL, YPW, AAB, GB, ShuP, JP, ShiP, JS, BDS, RW, and SZ wrote the paper.

Competing interests. The authors declare that they have no conflict of interest.

Acknowledgements. The idea of GOLUM was initially discussed at a workshop held at the Northwest Agricultural and Forestry University, China. We are grateful for the financial support of the workshop by the State Key Laboratory of Soil Erosion and Dryland Farming on the Loess Plateau of Northwest Agricultural and Forestry University and the National Basic Research Programme of China grant 2013CB956602. Funding was provided by the Laboratory for Sciences of Climate and Environment (LSCE), CEA, CNRS and UVSQ. Philippe Ciais, Daniel Goll, Shushi Peng, Josep Penuelas and Jordi Sardans acknowledge support from the European Research Council Synergy grant ERC-2013-SyG-610028 IMBALANCE-P. Contribution by A. Anthony Bloom was carried out at the Jet Propulsion Laboratory, California Institute of Technology, under a contract with the National Aeronautics and Space Administration. Benjamin D. Stocker, was funded by ERC H2020-MSCA-IF-2015, grant number 701329.

Edited by: Hisashi Sato

Reviewed by: two anonymous referees

\section{References}

Albergel, C., Dorigo, W., Reichle, R. H., Balsamo, G., De Rosnay, P., Muñoz-Sabater, J., Isaksen, L., De Jeu, R., and Wagner, W.: Skill and global trend analysis of soil moisture from reanalyses and microwave remote sensing, J. Hydrometeorol., 14, 12591277, 2013.

Augusto, L., Achat, D. L., Jonard, M., Vidal, D., and Ringeval, B.: Soil parent material - A major driver of plant nutrient limitations in terrestrial ecosystems, Glob. Change Biol., 23, 3808-3824, https://doi.org/10.1111/gcb.13691, 2017.

Bai, E., Houlton, B. Z., and Wang, Y. P.: Isotopic identification of nitrogen hotspots across natural terrestrial ecosystems, Biogeosciences, 9, 3287-3304, https://doi.org/10.5194/bg-9-32872012, 2012.

Balsamo, G., Albergel, C., Beljaars, A., Boussetta, S., Brun, E., Cloke, H., Dee, D., Dutra, E., Mu noz-Sabater, J., Pappenberger, F., de Rosnay, P., Stockdale, T., and Vitart, F.: ERAInterim/Land: a global land surface reanalysis data set, Hydrol. Earth Syst. Sci., 19, 389-407, https://doi.org/10.5194/hess-19389-2015, 2015.

Bloom, A. A. and Williams, M.: Constraining ecosystem carbon dynamics in a data-limited world: integrating ecological "common sense" in a model- data fusion framework, Biogeosciences, 12, 1299-1315, https://doi.org/10.5194/bg-12-1299-2015, 2015.

Bloom, A. A., Exbrayat, J.-F., Velde, I. R. van der, Feng, L., and Williams, M.: The decadal state of the terrestrial carbon cycle: Global retrievals of terrestrial carbon allocation, pools, and residence times, P. Natl. Acad. Sci. USA, 113, 1285-1290, https://doi.org/10.1073/pnas.1515160113, 2016.

Bontemps, S., Defourny, P., Radoux, J., Van Bogaert, E., Lamarche, C., Achard, F., Mayaux, P., Boettcher, M., Brockmann, C., Kirches, G., and others: Consistent global land cover maps for climate modelling communities: current achievements of the ESA's land cover CCI, in Proceedings of the ESA Living Planet Symposium, Edimburgh, 9-13, 2013.

Bouwman, A. F., Lee, D. S., Asman, W. a. H., Dentener, F. J., Van Der Hoek, K. W., and Olivier, J. G. J.: A global high-resolution emission inventory for ammonia, Global Biogeochem. Cy., 11, 561-587, https://doi.org/10.1029/97GB02266, 1997.

Chen, G., Yang, Y., and Robinson, D.: Allocation of gross primary production in forest ecosystems: allometric constraints and environmental responses, New Phytol., 200, 1176-1186, https://doi.org/10.1111/nph.12426, 2013.

Cleveland, C. C., Townsend, A. R., Schimel, D. S., Fisher, H., Howarth, R. W., Hedin, L. O., Perakis, S. S., Latty, E. F., Von Fischer, J. C., Elseroad, A., and Wasson, M. F.: Global patterns of terrestrial biological nitrogen $\left(\mathrm{N}_{2}\right)$ fixation in natural ecosystems, Global Biogeochem. Cy., 13, 623-645, https://doi.org/10.1029/1999GB900014, 1999.

Cleveland, C. C., Houlton, B. Z., Smith, W. K., Marklein, A. R., Reed, S. C., Parton, W., Grosso, S. J. D., and Running, S. W.: Patterns of new versus recycled primary production in the terrestrial biosphere, P. Natl. Acad. Sci. USA, 110, 12733-12737, https://doi.org/10.1073/pnas.1302768110, 2013.

Dentener, F. J.: Global Maps of Atmospheric Nitrogen Deposition, 1860, 1993, and 2050, https://doi.org/10.3334/ornldaac/830, 2006.

Dong, N., Prentice, I. C., Evans, B. J., Caddy-Retalic, S., Lowe, A. J., and Wright, I. J.: Leaf nitrogen from first principles: field evidence for adaptive variation with climate, Biogeosciences, 14, 481-495, https://doi.org/10.5194/bg-14-481-2017, 2017.

Doughty, C. E., Metcalfe, D. B., Girardin, C. A. J., Amézquita, F. F., Cabrera, D. G., Huasco, W. H., Silva-Espejo, J. E., AraujoMurakami, A., Da Costa, M. C., Rocha, W., Feldpausch, T. R., Mendoza, A. L. M., da Costa, A. C. L., Meir, P., Phillips, O. L. and Malhi, Y.: Drought impact on forest carbon dynamics and fluxes in Amazonia, Nature, 519, 78-82, 2015.

Elser, J. J., Bracken, M. E. S., Cleland, E. E., Gruner, D. S., Harpole, W. S., Hillebrand, H., Ngai, J. T., Seabloom, E. W., Shurin, J. B., and Smith, J. E.: Global analysis of nitrogen and phosphorus limitation of primary producers in freshwater, marine and terrestrial ecosystems, Ecol. Lett., 10, 1135-1142, https://doi.org/10.1111/j.1461-0248.2007.01113.x, 2007.

Fekete, B. M., Vörösmarty, C. J., and Grabs, W.: High-resolution fields of global runoff combining observed river discharge and simulated water balances, Global Biogeochem. Cy., 16, 54, https://doi.org/10.1029/1999GB0012, 2002.

Freney, J. R., Simpson, J. R., and Denmead, O. T.: Volatilization of ammonia, in Gaseous loss of nitrogen from plant-soil systems, Springer, Dordrecht, 1-32, 1983. 
Friedlingstein, P., Cox, P., Betts, R., Bopp, L., von Bloh, W., Brovkin, V., Cadule, P., Doney, S., Eby, M., Fung, I., Bala, G., John, J., Jones, C., Joos, F., Kato, T., Kawamiya, M., Knorr, W., Lindsay, K., Matthews, H. D., Raddatz, T., Rayner, P., Reick, C., Roeckner, E., Schnitzler, K.-G., Schnur, R., Strassmann, K., Weaver, A. J., Yoshikawa, C., and Zeng, N.: Climate-carbon cycle feedback analysis: results from the C4MIP model intercomparison, J. Climate, 19, 3337-3353, 2006.

Galloway, J. N., Dentener, F. J., Capone, D. G., Boyer, E. W., Howarth, R. W., Seitzinger, S. P., Asner, G. P., Cleveland, C. C., Green, P. A., Holland, E. A., Karl, D. M., Michaels, A. F., Porter, J. H., Townsend, A. R., and Vöosmarty, C. J.: Nitrogen Cycles: Past, Present, and Future, Biogeochemistry, 70, 153-226, https://doi.org/10.1007/s10533-004-0370-0, 2004.

Galloway, J. N., Dentener, F. J., Capone, D. G., Boyer, E. W., Howarth, R. W., Seitzinger, S. P., Asner, G. P., Cleveland, C. C., Green, P. A., Holland, E. A., Karl, D. M., Michaels, A. F., Porter, J. H., Townsend, A. R., and Vöosmarty, C. J.: Nitrogen Cycles: Past, Present, and Future, Biogeochemistry, 70, 153-226, https://doi.org/10.1007/s10533-004-0370-0, 2004.

Galloway, J. N., Leach, A. M., Bleeker, A., and Erisman, J. W.: A chronology of human understanding of the nitrogen cycle, Philos. T. R. Soc. B, 368, 20130120, https://doi.org/10.1098/rstb.2013.0120, 2013.

Gärdenäs, A. I., Ågren, G. I., Bird, J. A., Clarholm, M., Hallin, S., Ineson, P., Kätterer, T., Knicker, H., Nilsson, S. I., Näsholm, T., Ogle, S., Paustian, K., Persson, T., and Stendahl, J.: Knowledge gaps in soil carbon and nitrogen interactions - From molecular to global scale, Soil Biol. Biochem., 43, 702-717, https://doi.org/10.1016/j.soilbio.2010.04.006, 2011.

Giglio, L., Randerson, J. T., and Werf, G. R.: Analysis of daily, monthly, and annual burned area using the fourth-generation global fire emissions database (GFED4), J. Geophys. Res.Biogeo., 118, 317-328, 2013.

Gill, A. L. and Finzi, A. C.: Belowground carbon flux links biogeochemical cycles and resource-use efficiency at the global scale, Ecol. Lett., 19, 1419-1428, https://doi.org/10.1111/ele.12690, 2016.

Gill, R. A. and Jackson, R. B.: Global patterns of root turnover for terrestrial ecosystems, New Phytol., 147, 13-31, https://doi.org/10.1046/j.1469-8137.2000.00681.x, 2000.

Goll, D. S., Brovkin, V., Parida, B. R., Reick, C. H., Kattge, J., Reich, P. B., van Bodegom, P. M., and Niinemets, Ü.: Nutrient limitation reduces land carbon uptake in simulations with a model of combined carbon, nitrogen and phosphorus cycling, Biogeosciences, 9, 3547-3569, https://doi.org/10.5194/bg-9-35472012, 2012.

Goll, D. S., Vuichard, N., Maignan, F., Jornet-Puig, A., Sardans, J., Violette, A., Peng, S., Sun, Y., Kvakic, M., Guimberteau, M., Guenet, B., Zaehle, S., Penuelas, J., Janssens, I., and Ciais, P.: A representation of the phosphorus cycle for ORCHIDEE (revision 4520), Geosci. Model Dev., 10, 3745-3770, https://doi.org/10.5194/gmd-10-3745-2017, 2017a.

Goll, D. S., Winkler, A. J., Raddatz, T., Dong, N., Prentice, I. C., Ciais, P., and Brovkin, V.: Carbon-nitrogen interactions in idealized simulations with JSBACH (version 3.10), Geosci. Model Dev., 10, 2009-2030, https://doi.org/10.5194/gmd-102009-2017, 2017b.
Gordon, W. S. and Jackson, R. B.: Nutrient concentrations in fine roots, Ecology, 81, 275-280, 2000.

Green, J. J., Dawson, L. A., Proctor, J., Duff, E. I., and Elston, D. A.: Fine Root Dynamics in a Tropical Rain Forest is Influenced by Rainfall, Plant Soil, 276, 23-32, https://doi.org/10.1007/s11104004-0331-3, 2005.

Gruber, N. and Galloway, J. N.: An Earth-system perspective of the global nitrogen cycle, Nature, 451, 293-296, https://doi.org/10.1038/nature06592, 2008.

Han, W., Fang, J., Guo, D., and Zhang, Y.: Leaf nitrogen and phosphorus stoichiometry across 753 terrestrial plant species in China, New Phytol., 168, 377-385, https://doi.org/10.1111/j.1469-8137.2005.01530.x, 2005.

Hartmann, J., Moosdorf, N., Lauerwald, R., Hinderer, M., and West, A. J.: Global chemical weathering and associated P-release - The role of lithology, temperature and soil properties, Chem. Geol., 363, 145-163, https://doi.org/10.1016/j.chemgeo.2013.10.025, 2014.

Heiskanen, J., Rautiainen, M., Stenberg, P., Mõttus, M., Vesanto, V.-H., Korhonen, L., and Majasalmi, T.: Seasonal variation in MODIS LAI for a boreal forest area in Finland, Remote Sens. Environ., 126, 104-115, 2012.

Hiederer, R. and Köchy, M.: Global soil organic carbon estimates and the harmonized world soil database, EUR, 79, 25225, https://doi.org/10.2788/1326, 2011.

Houlton, B. Z. and Bai, E.: Imprint of denitrifying bacteria on the global terrestrial biosphere, P. Natl. Acad. Sci. USA, 106, 21713 21716, https://doi.org/10.1073/pnas.0912111106, 2009.

Houlton, B. Z., Marklein, A. R., and Bai, E.: Representation of nitrogen in climate change forecasts, Nat. Clim. Change, 5, 398401, https://doi.org/10.1038/nclimate2538, 2015.

Houlton, B. Z., Morford, S. L., and Dahlgren, R. A.: Convergent evidence for widespread rock nitrogen sources in Earth's surface environment, Science, 360, 58-62, https://doi.org/10.1126/science.aan4399, 2018.

Hungate, B. A., Dukes, J. S., Shaw, M. R., Luo, Y., and Field, C. B.: Nitrogen and Climate Change, Science, 302, 1512-1513, https://doi.org/10.1126/science.1091390, 2003.

Jahnke, R. A.: The phosphorus cycle, in Earth system science: From biogeochemical cycles to global change, Elservier Academic Press, San Diego, 360-376, 2000.

Kattge, J., Díaz, S., Lavorel, S., Prentice, I. C., Leadley, P., Bönisch, G., Garnier, E., Westoby, M., Reich, P. B., Wright, I. J., Cornelissen, J. H. C., Violle, C., Harrison, S. P., Van Bodegom, P. M., Reichstein, M., Enquist, B. J., Soudzilovskaia, N. A., Ackerly, D. D., Anand, M., Atkin, O., Bahn, M., Baker, T. R., Baldocchi, D., Bekker, R., Blanco, C. C., Blonder, B., Bond, W. J., Bradstock, R., Bunker, D. E., Casanoves, F., CavenderBares, J., Chambers, J. Q., Chapin Iii, F. S., Chave, J., Coomes, D., Cornwell, W. K., Craine, J. M., Dobrin, B. H., Duarte, L., Durka, W., Elser, J., Esser, G., Estiarte, M., Fagan, W. F., Fang, J., Fernández-Méndez, F., Fidelis, A., Finegan, B., Flores, O., Ford, H., Frank, D., Freschet, G. T., Fyllas, N. M., Gallagher, R. V., Green, W. A., Gutierrez, A. G., Hickler, T., Higgins, S. I., Hodgson, J. G., Jalili, A., Jansen, S., Joly, C. A., Kerkhoff, A. J., Kirkup, D., Kitajima, K., Kleyer, M., Klotz, S., Knops, J. M. H., Kramer, K., Kühn, I., Kurokawa, H., Laughlin, D., Lee, T. D., Leishman, M., Lens, F., Lenz, T., Lewis, S. L., Lloyd, J., Llusià, J., Louault, F., Ma, S., Mahecha, M. D., Manning, P., 
Massad, T., Medlyn, B. E., Messier, J., Moles, A. T., Müller, S. C., Nadrowski, K., Naeem, S., Niinemets, Ü., Nöllert, S., Nüske, A., Ogaya, R., Oleksyn, J., Onipchenko, V. G., Onoda, Y., Ordoñez, J., Overbeck, G., Ozinga, W. A., Patiño, S., Paula, S., Pausas, J. G., Peñuelas, J., Phillips, O. L., Pillar, V., Poorter, H., Poorter, L., Poschlod, P., Prinzing, A., Proulx, R., Rammig, A., Reinsch, S., Reu, B., Sack, L., Salgado-Negret, B., Sardans, J., Shiodera, S., Shipley, B., Siefert, A., Sosinski, E., Soussana, J., Swaine, E., Swenson, N., Thompson, K., Thornton, P., Waldram, M., Weiher, E., White, M., White, S., Wright, S. J., Yguel, B., Zaehle, S., Zanne, A. E., and Wirth, C.: TRY - a global database of plant traits, Glob. Change Biol., 17, 2905-2935, https://doi.org/10.1111/j.1365-2486.2011.02451.x, 2011.

Kerkhoff, A. J., Enquist, B. J., Elser, J. J., and Fagan, W. F.: Plant allometry, stoichiometry and the temperature-dependence of primary productivity, Global Ecol. Biogeogr., 14, 585-598, https://doi.org/10.1111/j.1466-822X.2005.00187.x, 2005.

Klodd, A. E., Nippert, J. B., Ratajczak, Z., Waring, H., and Phoenix, G. K.: Tight coupling of leaf area index to canopy nitrogen and phosphorus across heterogeneous tallgrass prairie communities, Oecologia, 182, 889-898, https://doi.org/10.1007/s00442-0163713-3, 2016.

Liu, Y., Wang, C., He, N., Wen, X., Gao, Y., Li, S., Niu, S., Butterbach-Bahl, K., Luo, Y., and Yu, G.: A global synthesis of the rate and temperature sensitivity of soil nitrogen mineralization: latitudinal patterns and mechanisms, Glob. Change Biol., 23, 455-464, https://doi.org/10.1111/gcb.13372, 2017.

Luo, Y. and Weng, E.: Dynamic disequilibrium of the terrestrial carbon cycle under global change, Trends Ecol. Evol., 26, 96-104, 2011.

Mahowald, N., Jickells, T. D., Baker, A. R., Artaxo, P., BenitezNelson, C. R., Bergametti, G., Bond, T. C., Chen, Y., Cohen, D. D., Herut, B., Kubilay, N., Losno, R., Luo, C., Maenhaut, W., McGee, K. A., Okin, G. S., Siefert, R. L., and Tsukuda, S.: Global distribution of atmospheric phosphorus sources, concentrations and deposition rates, and anthropogenic impacts, Global Biogeochem. Cy., 22, GB4026, https://doi.org/10.1029/2008GB003240, 2008.

Manzoni, S., Trofymow, J. A., Jackson, R. B., and Porporato, A.: Stoichiometric controls on carbon, nitrogen, and phosphorus dynamics in decomposing litter, Ecol. Monogr., 80, 89-106, 2010.

Manzoni, S., Čapek, P., Mooshammer, M., Lindahl, B. D., Richter, A., and Šantrůčková, H.: Optimal metabolic regulation along resource stoichiometry gradients, Ecol. Lett., 20, 1182-1191, https://doi.org/10.1111/ele.12815, 2017.

Mayor, J. R., Wright, S. J., and Turner, B. L.: Species-specific responses of foliar nutrients to long-term nitrogen and phosphorus additions in a lowland tropical forest, J. Ecol., 102, 36-44, https://doi.org/10.1111/1365-2745.12190, 2014.

McGroddy, M. E., Daufresne, T., and Hedin, L. O.: Scaling of C:n:p Stoichiometry in Forests Worldwide: Implications of Terrestrial Redfield-Type Ratios, Ecology, 85, 2390-2401, https://doi.org/10.1890/03-0351, 2004.

Medvigy, D., Wofsy, S. C., Munger, J. W., Hollinger, D. Y., and Moorcroft, P. R.: Mechanistic scaling of ecosystem function and dynamics in space and time: Ecosystem Demography model version 2, J. Geophys. Res.-Biogeo., 114, G01002, https://doi.org/10.1029/2008JG000812, 2009.
Melillo, J. M., Butler, S., Johnson, J., Mohan, J., Steudler, P., Lux, H., Burrows, E., Bowles, F., Smith, R., Scott, L., Vario, C., Hill, T., Burton, A., Zhou, Y.-M., and Tang, J.: Soil warming, carbonnitrogen interactions, and forest carbon budgets, P. Natl. Acad. Sci. USA, 108, 9508-9512, 2011.

Meyerholt, J. and Zaehle, S.: The role of stoichiometric flexibility in modelling forest ecosystem responses to nitrogen fertilization, New Phytol., 208, 1042-1055, https://doi.org/10.1111/nph.13547, 2015.

Myneni, R., Knyazikhin, Y., and Park, T.: MOD15A2H MODIS/Terra Leaf Area Index/FPAR 8-Day L4 Global 500m SIN Grid V006, 2015.

Näsholm, T., Kielland, K., and Ganeteg, U.: Uptake of organic nitrogen by plants, New Phytol., 182, 31-48, https://doi.org/10.1111/j.1469-8137.2008.02751.x, 2009.

Niemeyer, T., Niemeyer, M., Mohamed, A., Fottner, S., and Härdtle, W.: Impact of prescribed burning on the nutrient balance of heathlands with particular reference to nitrogen and phosphorus, Appl. Veg. Sci., 8, 183-192, 2005.

Norby, R. J., Warren, J. M., Iversen, C. M., Medlyn, B. E., and McMurtrie, R. E.: $\mathrm{CO}_{2}$ enhancement of forest productivity constrained by limited nitrogen availability, P. Natl. Acad. Sci. USA, 107, 19368-19373, https://doi.org/10.1073/pnas.1006463107, 2010.

Orwin, K. H., Kirschbaum, M. U. F., St John, M. G., and Dickie, I. A.: Organic nutrient uptake by mycorrhizal fungi enhances ecosystem carbon storage: a model-based assessment, Ecol. Lett., 14, 493-502, https://doi.org/10.1111/j.14610248.2011.01611.x, 2011.

Pan, Y., Birdsey, R. A., Fang, J., Houghton, R., Kauppi, P. E., Kurz, W. A., Phillips, O. L., Shvidenko, A., Lewis, S. L., Canadell, J. G., Ciais, P., Jackson, R. B., Pacala, S. W., McGuire, A. D., Piao, S., Rautiainen, A., Sitch, S., and Hayes, D.: A large and persistent carbon sink in the world's forests, Science, 333, 988993, https://doi.org/10.1126/science.1201609, 2011.

Parton, W. J., Hanson, P. J., Swanston, C., Torn, M., Trumbore, S. E., Riley, W., and Kelly, R.: ForCent model development and testing using the Enriched Background Isotope Study experiment, J. Geophys. Res.-Biogeo., 115, G04001, https://doi.org/10.1029/2009JG001193, 2010.

Peng, J., Wang, Y.-P., and Houlton, B. Z.: Estimates of biological nitrogen fixation and implication of land carbon uptake from 1901 to 2100, Global Biogeochem. Cy., in review, 2018.

Peñuelas, J., Poulter, B., Sardans, J., Ciais, P., Velde, M. van der, Bopp, L., Boucher, O., Godderis, Y., Hinsinger, P., Llusia, J., Nardin, E., Vicca, S., Obersteiner, M., and Janssens, I. A.: Human-induced nitrogen-phosphorus imbalances alter natural and managed ecosystems across the globe, Nat. Commun., 4, ncomms3934, https://doi.org/10.1038/ncomms3934, 2013.

Poulter, B., MacBean, N., Hartley, A., Khlystova, I., Arino, O., Betts, R., Bontemps, S., Boettcher, M., Brockmann, C., Defourny, P., Hagemann, S., Herold, M., Kirches, G., Lamarche, C., Lederer, D., Ottlé, C., Peters, M., and Peylin, P.: Plant functional type classification for earth system models: results from the European Space Agency's Land Cover Climate Change Initiative, Geosci. Model Dev., 8, 2315-2328, https://doi.org/10.5194/gmd8-2315-2015, 2015. 
Qian, Y., Miao, S. L., Gu, B., and Li, Y. C.: Estimation of postfire nutrient loss in the Florida Everglades, J. Environ. Qual., 38, 1812-1820, 2009.

Reich, P. B. and Oleksyn, J.: Global patterns of plant leaf N and P in relation to temperature and latitude, P. Natl. Acad. Sci. USA, 101, 11001-11006, 2004.

Reich, P. B., Oleksyn, J., Wright, I. J., Niklas, K. J., Hedin, L., and Elser, J. J.: Evidence of a general 2/3-power law of scaling leaf nitrogen to phosphorus among major plant groups and biomes, P. R. Soc. Lond. B Bio., 277, 877-883, https://doi.org/10.1098/rspb.2009.1818, 2010.

Reich, P. B., Rich, R. L., Lu, X., Wang, Y.-P., and Oleksyn, J.: Biogeographic variation in evergreen conifer needle longevity and impacts on boreal forest carbon cycle projections, P. Natl. Acad. Sci. USA, 111, 13703-13708, 2014.

Rötzer, K., Montzka, C., and Vereecken, H.: Spatio-temporal variability of global soil moisture products, J. Hydrol., 522, 187-202, https://doi.org/10.1016/j.jhydrol.2014.12.038, 2015.

Saatchi, S. S., Harris, N. L., Brown, S., Lefsky, M., Mitchard, E. T., Salas, W., Zutta, B. R., Buermann, W., Lewis, S. L., Hagen, S., Petrova, S., White, L., Silman, M., and Morel, A.: Benchmark map of forest carbon stocks in tropical regions across three continents, P. Natl. Acad. Sci. USA, 108, 9899-9904, 2011.

Sardans, J. and Peñuelas, J.: The role of plants in the effects of global change on nutrient availability and stoichiometry in the plant-soil system, Plant Physiol., 160, 1741-1761, https://doi.org/10.1104/pp.112.208785, 2012.

Sardans, J., Rivas-Ubach, A., and Peñuelas, J.: The C : N : P stoichiometry of organisms and ecosystems in a changing world: A review and perspectives, Perspect. Plant Ecol., 14, 33-47, https://doi.org/10.1016/j.ppees.2011.08.002, 2012.

Sardans, J., Alonso, R., Janssens, I. A., Carnicer, J., Vereseglou, S., Rillig, M. C., Fernández-Martínez, M., Sanders, T. G. M., and Peñuelas, J.: Foliar and soil concentrations and stoichiometry of nitrogen and phosphorous across European Pinus sylvestris forests: relationships with climate, $\mathrm{N}$ deposition and tree growth, Funct. Ecol., 30, 676-689, https://doi.org/10.1111/13652435.12541, 2016.

Sardans, J., Grau, O., Chen, H. Y. H., Janssens, I. A., Ciais, P., Piao, S., and Peñuelas, J.: Changes in nutrient concentrations of leaves and roots in response to global change factors, Glob. Change Biol., 23, 3849-3856, https://doi.org/10.1111/gcb.13721, 2017.

Schimel, J. P. and Bennett, J.: Nitrogen mineralization: challenges of a changing paradigm, Ecology, 85, 591-602, 2004.

Schimel, J. P. and Chapin, F. S.: Tundra Plant Uptake of Amino Acid and $\mathrm{NH}_{4}^{+}$Nitrogen in Situ: Plants Complete Well for Amino Acid N, Ecology, 77, 2142-2147, https://doi.org/10.2307/2265708, 1996.

Seitzinger, S., Harrison, J. A., Böhlke, J. K., Bouwman, A. F., Lowrance, R., Peterson, B., Tobias, C., and Drecht, G. V.: Denitrification across landscapes and waterscapes: a synthesis, Ecol. Appl., 16, 2064-2090, 2006.

Shi, Z., Yang, Y., Zhou, X., Weng, E., Finzi, A. C., and Luo, Y.: Inverse analysis of coupled carbon-nitrogen cycles against multiple datasets at ambient and elevated $\mathrm{CO}_{2}$, J. Plant Ecol., 9, 285295, 2016.

Sistla, S. A. and Schimel, J. P.: Stoichiometric flexibility as a regulator of carbon and nutrient cycling in terres- trial ecosystems under change, New Phytol., 196, 68-78, https://doi.org/10.1111/j.1469-8137.2012.04234.x, 2012.

Sitch, S., Friedlingstein, P., Gruber, N., Jones, S. D., MurrayTortarolo, G., Ahlström, A., Doney, S. C., Graven, H., Heinze, C., Huntingford, C., Levis, S., Levy, P. E., Lomas, M., Poulter, B., Viovy, N., Zaehle, S., Zeng, N., Arneth, A., Bonan, G., Bopp, L., Canadell, J. G., Chevallier, F., Ciais, P., Ellis, R., Gloor, M., Peylin, P., Piao, S. L., Le Quéré, C., Smith, B., Zhu, Z., and Myneni, R.: Recent trends and drivers of regional sources and sinks of carbon dioxide, Biogeosciences, 12, 653679, https://doi.org/10.5194/bg-12-653-2015, 2015.

Sun, Y., Peng, S., Goll, D. S., Ciais, P., Guenet, B., Guimberteau, M., Hinsinger, P., Janssens, I. A., Peñuelas, J., Piao, S., Poulter, B., Violette, A., Yang, X., Yin, Y., and Zeng, H.: Diagnosing phosphorus limitations in natural terrestrial ecosystems in carbon cycle models, Earths Future, 5, 730-749, https://doi.org/10.1002/2016EF000472, 2017.

Sutton, M. A., Simpson, D., Levy, P. E., Smith, R. I., Reis, S., Van Oijen, M., and De Vries, W. I. M.: Uncertainties in the relationship between atmospheric nitrogen deposition and forest carbon sequestration, Glob. Change Biol., 14, 2057-2063, 2008.

Thornton, P. E., Lamarque, J.-F., Rosenbloom, N. A., and Mahowald, N. M.: Influence of carbon-nitrogen cycle coupling on land model response to $\mathrm{CO}_{2}$ fertilization and climate variability, Global Biogeochem. Cy., 21, GB4018, https://doi.org/10.1029/2006GB002868, 2007.

Thurner, M., Beer, C., Santoro, M., Carvalhais, N., Wutzler, T., Schepaschenko, D., Shvidenko, A., Kompter, E., Ahrens, B., Levick, S. R., and Schmullius, C.: Carbon stock and density of northern boreal and temperate forests, Global Ecol. Biogeogr., 23, 297-310, https://doi.org/10.1111/geb.12125, 2014.

Turner, B. L., Brenes-Arguedas, T., and Condit, R.: Pervasive phosphorus limitation of tree species but not communities in tropical forests, Nature, 555, 367-370, https://doi.org/10.1038/nature25789, 2018.

Ver, L. M. B., Mackenzie, F. T., and Lerman, A.: Biogeochemical responses of the carbon cycle to natural and human perturbations; past, present, and future, Am. J. Sci., 299, 762-801, 1999.

Vitousek, P. M. and Howarth, R. W.: Nitrogen limitation on land and in the sea: how can it occur?, Biogeochemistry, 13, 87-115, 1991.

Vitousek, P. M., Menge, D. N. L., Reed, S. C., and Cleveland, C. C.: Biological nitrogen fixation: rates, patterns and ecological controls in terrestrial ecosystems, Philos. T. R. Soc. B, 368, 1621, https://doi.org/10.1098/rstb.2013.0119, 2013.

Wang, R., Balkanski, Y., Boucher, O., Ciais, P., Peñuelas, J., and Tao, S.: Significant contribution of combustion-related emissions to the atmospheric phosphorus budget, Nat. Geosci., 8, 48-54, https://doi.org/10.1038/ngeo2324, 2015.

Wang, R., Goll, D., Balkanski, Y., Hauglustaine, D., Boucher, O., Ciais, P., Janssens, I., Penuelas, J., Guenet, B., Sardans, J., Bopp, L., Vuichard, N., Zhou, F., Li, B., Piao, S., Peng, S., Huang, Y., and Tao, S.: Global forest carbon uptake due to nitrogen and phosphorus deposition from 1850 to 2100 , Glob. Change Biol., https://doi.org/10.1111/gcb.13766, online first, 2017.

Wang, S., Grant, R. F., Verseghy, D. L., and Black, T. A.: Modelling plant carbon and nitrogen dynamics of a boreal aspen forest in CLASS - the Canadian Land Surface Scheme, Ecol. Model., 
142, 135-154, https://doi.org/10.1016/S0304-3800(01)00284-8, 2001.

Wang, Y.-P., Houlton, B. Z., and Field, C. B.: A model of biogeochemical cycles of carbon, nitrogen, and phosphorus including symbiotic nitrogen fixation and phosphatase production, Global Biogeochem. Cy., 21, GB1018, https://doi.org/10.1029/2006GB002797, 2007.

Wang, Y. P., Law, R. M., and Pak, B.: A global model of carbon, nitrogen and phosphorus cycles for the terrestrial biosphere, Biogeosciences, 7, 2261-2282, https://doi.org/10.5194/bg-7-22612010, 2010.

Wang, Y.-P. and Houlton, B. Z.: Nitrogen constraints on terrestrial carbon uptake: Implications for the global carbon-climate feedback, Geophys. Res. Lett., 36, L24403, https://doi.org/10.1029/2009GL041009, 2009.

Weng, E. and Luo, Y.: Soil hydrological properties regulate grassland ecosystem responses to multifactor global change: A modeling analysis, J. Geophys. Res.-Biogeo., 113, https://doi.org/10.1029/2007JG00053, 2008.

Wieder, W. R., Cleveland, C. C., Smith, W. K., and ToddBrown, K.: Future productivity and carbon storage limited by terrestrial nutrient availability, Nat. Geosci., 8, 441-444, https://doi.org/10.1038/ngeo2413, 2015.

Williams, M., Schwarz, P. A., Law, B. E., Irvine, J., and Kurpius, M. R.: An improved analysis of forest carbon dynamics using data assimilation, Glob. Change Biol., 11, 89-105, 2005.

Williams, M., Hill, T. C., and Ryan, C. M.: Using biomass distributions to determine probability and intensity of tropical forest disturbance, Plant Ecol. Divers., 6, 87-99, https://doi.org/10.1080/17550874.2012.692404, 2013.

Xu-Ri and Prentice, I. C.: Terrestrial nitrogen cycle simulation with a dynamic global vegetation model, Glob. Change Biol., 14, 1745-1764, https://doi.org/10.1111/j.1365-2486.2008.01625.x, 2008.

Yang, X. and Post, W. M.: Phosphorus transformations as a function of pedogenesis: A synthesis of soil phosphorus data using Hedley fractionation method, Biogeosciences, 8, 2907-2916, https://doi.org/10.5194/bg-8-2907-2011, 2011.

Yang, X., Wittig, V., Jain, A. K., and Post, W.: Integration of nitrogen cycle dynamics into the Integrated Science Assessment Model for the study of terrestrial ecosystem responses to global change, Global Biogeochem. Cy., 23, https://doi.org/10.1029/2009GB003474, 2009.

Yang, X., Post, W. M., Thornton, P. E., and Jain, A.: The distribution of soil phosphorus for global biogeochemical modeling, Biogeosciences, 10, 2525-2537, https://doi.org/10.5194/bg-102525-2013, 2013.

Yang, X., Thornton, P. E., Ricciuto, D. M., and Post, W. M.: The role of phosphorus dynamics in tropical forests - a modeling study using CLM-CNP, Biogeosciences, 11, 1667-1681, https://doi.org/10.5194/bg-11-1667-2014, 2014a.
Yang, Y., Fang, J., Ji, C., Datta, A., Li, P., Ma, W., Mohammat, A., Shen, H., Hu, H., Knapp, B. O., and Smith, P.: Stoichiometric shifts in surface soils over broad geographical scales: evidence from China's grasslands, Global Ecol. Biogeogr., 23, 947-955, https://doi.org/10.1111/geb.12175, 2014b.

Yuan, Z. Y. and Chen, H. Y. H.: Decoupling of nitrogen and phosphorus in terrestrial plants associated with global changes, Nat. Clim. Change, 5, 465-469, https://doi.org/10.1038/nclimate2549, 2015.

Zaehle, S.: Terrestrial nitrogen-carbon cycle interactions at the global scale, Philos. T. R. Soc. B, 368, 20130125, https://doi.org/10.1098/rstb.2013.0125, 2013.

Zaehle, S. and Dalmonech, D.: Carbon-nitrogen interactions on land at global scales: current understanding in modelling climate biosphere feedbacks, Curr. Opin. Env. Sust., 3, 311-320, https://doi.org/10.1016/j.cosust.2011.08.008, 2011.

Zaehle, S. and Friend, A. D.: Carbon and nitrogen cycle dynamics in the O-CN land surface model: 1. Model description, site-scale evaluation, and sensitivity to parameter estimates, Global Biogeochem. Cy., 24, GB1005, https://doi.org/10.1029/2009GB003521, 2010.

Zaehle, S., Medlyn, B. E., De Kauwe, M. G., Walker, A. P., Dietze, M. C., Hickler, T., Luo, Y., Wang, Y.-P., El-Masri, B., Thornton, P., Jain, A., Wang, S., Warlind, D., Weng, E., Parton, W., Iversen, C. M., Gallet-Budynek, A., McCarthy, H., Finzi, A., Hanson, P. J., Prentice, I. C., Oren, R., and Norby, R. J.: Evaluation of 11 terrestrial carbon-nitrogen cycle models against observations from two temperate Free-Air $\mathrm{CO}_{2}$ Enrichment studies, New Phytol., 202, 803-822, https://doi.org/10.1111/nph.12697, 2014.

Zaehle, S., Jones, C. D., Houlton, B., Lamarque, J.-F., and Robertson, E.: Nitrogen availability reduces CMIP5 projections of twenty-first-century land carbon uptake, J. Climate, 28, 24942511, 2015.

Zechmeister-Boltenstern, S., Keiblinger, K. M., Mooshammer, M., Peñuelas, J., Richter, A., Sardans, J., and Wanek, W.: The application of ecological stoichiometry to plant-microbial-soil organic matter transformations, Ecol. Monogr., 85, 133-155, 2015.

Zhang, Q., Wang, Y. P., Pitman, A. J., and Dai, Y. J.: Limitations of nitrogen and phosphorous on the terrestrial carbon uptake in the 20th century, Geophys. Res. Lett., 38, L22701, https://doi.org/10.1029/2011GL049244, 2011.

Zhu, Q. and Zhuang, Q.: Modeling the effects of organic nitrogen uptake by plants on the carbon cycling of boreal forest and tundra ecosystems, Biogeosciences, 10, 7943-7955, https://doi.org/10.5194/bg-10-7943-2013, 2013. 